\title{
Targeting the PI3K/Akt/mTOR pathway in castration-resistant prostate cancer
}

\author{
Rhonda L Bitting and Andrew J Armstrong \\ Divisions of Medical Oncology and Urology, Duke Cancer Institute, Duke University, DUMC Box 102002, Durham, \\ North Carolina 27710, USA
}

Correspondence should be addressed to A J Armstrong Email andrew.armstrong@duke.edu

\begin{abstract}
The phosphatidylinositol 3-kinase (PI3K)/Akt/mammalian target of rapamycin (mTOR) pathway is a key signaling pathway that has been linked to both tumorigenesis and resistance to therapy in prostate cancer and other solid tumors. Given the significance of the $\mathrm{PI3K} / \mathrm{Akt} / \mathrm{mTOR}$ pathway in integrating cell survival signals and the high prevalence of activating PI3K/Akt/mTOR pathway alterations in prostate cancer, inhibitors of this pathway have great potential for clinical benefit. Here, we review the role of the PI3K/Akt/mTOR pathway in prostate cancer and discuss the potential use of pathway inhibitors as single agents or in combination in the evolving treatment landscape of castration-resistant prostate cancer.

\author{
Key Words \\ - castration-resistant \\ prostate cancer (CRPC) \\ - PI3K inhibitors \\ - mTOR \\ - PI3K pathway \\ - Akt \\ - combination therapy \\ Endocrine-Related Cancer \\ (2013) 20, R83-R99
}

- androgen receptor signaling
\end{abstract}

\section{Introduction}

Prostate cancer is the second most common cancer and sixth leading cause of cancer-related mortality in men, accounting for 903500 new diagnoses and 258400 deaths per year worldwide (Jemal et al. 2011). Although the prognosis for patients with localized or regional disease is good, for patients in the United States who develop metastatic disease, the 5-year survival rate is only $29 \%$ (Siegel et al. 2012). Currently, androgen deprivation therapy through either chemical or surgical castration is the first-line therapy for metastatic disease. Response to therapy, however, is temporary, and patients invariably progress to castration-resistant prostate cancer (CRPC; Rini \& Small 2002). The TAX327 trial established docetaxel plus prednisone as the standard-of-care firstline chemotherapy for CRPC (Berthold et al. 2008), and until recently, treatment of CRPC was limited, with only docetaxel-based regimens offering a survival benefit
(Petrylak et al. 2004, Berthold et al. 2008). Recently, several new therapies have emerged, including the novel taxane chemotherapeutic cabazitaxel (de Bono et al. 2010), the androgen synthesis inhibitor abiraterone acetate (de Bono et al. 2011), the novel androgen receptor (AR) inhibitor enzalutamide (Scher et al. 2012), the immunotherapeutic sipuleucel-T (Kantoff et al. 2010), and the bone microenvironment-targeted radiopharmaceutical alpharadin (Radium-223; Parker et al. 2012), leading to approval or submission for approval to regulatory agencies. While these therapies have established androgen synthesis and AR signaling, microtubule dynamics, and the bone microenvironment as targets for therapeutic intervention and have provided clinical benefit to men with metastatic CRPC, the survival rate of patients with metastatic CRPC remains poor and additional therapeutic approaches are needed.

Published by Bioscientifica Ltd 
The phosphatidylinositol 3-kinase (PI3K)/Akt/mammalian target of rapamycin (mTOR) pathway is a key oncogenic signaling pathway that has been linked to tumorigenesis and resistance to both conventional and targeted anticancer therapies in a wide variety of tumor types (Courtney et al. 2010, McCubrey et al. 2011). In prostate cancer, activation of the PI3K/Akt/mTOR pathway has been strongly implicated in prostate cancer progression (Pourmand et al. 2007, Reid et al. 2010, Taylor et al. 2010). Here, we review the role of the $\mathrm{PI} 3 \mathrm{~K} / \mathrm{Akt} / \mathrm{mTOR}$ pathway in prostate cancer and discuss the potential of PI3K/Akt/mTOR pathway inhibitors as single agents or in combination with other agents in the currently evolving treatment landscape of CRPC.

\section{The PI3K/Akt/mTOR signaling pathway}

The PI3K/Akt/mTOR signaling pathway has a diverse array of functions, including the regulation of cellular survival, differentiation and stem cell-like properties, growth, proliferation, metabolism, migration, and angiogenesis (Guba et al. 2002, Dubrovska et al. 2009, Liu et al. 2009, Courtney et al. 2010, Furic et al. 2010, Hsieh et al. 2012). There are three classes of PI3K that are differentiated by their structural characteristics and substrate specificities (Courtney et al. 2010). Class I PI3Ks are activated by receptor tyrosine kinases (RTKs), G-protein-coupled receptors, and some oncogenes, such as rat sarcoma oncogene (RAS), and can be further subdivided into class IA and IB, of which class IA PI3Ks are most frequently implicated in cancer. Class IA PI3Ks consist of two subunits: a regulatory subunit, $\mathrm{p} 85$, and a catalytic subunit, p110. There are three isoforms of p85 (p85a, $\mathrm{p} 85 \beta$, and $\mathrm{p} 55 \gamma$ ) encoded by the genes PIK3R1, PIK3R2, and PIK3R3 respectively and three isoforms of class IA p110 $(\alpha, \beta$, and $\delta)$ encoded by the genes PIK3CA, PIK3CB, and PIK3CD respectively (Courtney et al. 2010). Activation of PI3K leads to the phosphorylation of phosphatidylinositol 4,5-bisphosphate $\left[\mathrm{PI}(4,5) \mathrm{P}_{2}\right]$ to phosphatidylinositol 3,4,5-trisphosphate $\left[\mathrm{PI}(3,4,5) \mathrm{P}_{3}\right]$ and subsequent recruitment of Akt to the plasma membrane where Akt is activated (Liu et al. 2009, Courtney et al. 2010). Akt activation is mediated through phosphorylation at two residues: T308 by phosphoinositide-dependent kinase-1 and S473 by the mTOR complex 2 (TORC2). Both phosphorylation events are required for full activation of Akt (Sarbassov et al. 2005). Upon activation, Akt phosphorylates a host of other proteins including glycogen synthase kinase 3 (GSK3), FOXO transcription factors, and tuberous sclerosis complex (TSC) and thereby regulates a range of cellular processes, including protein synthesis, cell survival, proliferation, and metabolism (Fig. 1; Liu et al. 2009, Courtney et al. 2010). In prostate cancer, PI3K signaling has been shown to repress AR transcriptional activity, illustrating the lineage-specific complexity of this pathway (Fig. 2; Carver et al. 2011).

mTOR is a serine threonine kinase and is the catalytic subunit of the functionally distinct TORC1 and TORC2. TORC1 is a major downstream effector of Akt signaling and is activated via Akt-mediated inhibition of TSC. Depending on available nutrients and the cellular environment, TORC1 controls the growth of the cell through phosphorylation of $\mathrm{S} 6 \mathrm{~K}$ and the eukaryotic initiation factor 4E-binding protein 1 (4E-BP1; Sparks \& Guertin 2010). TORC2 does not bind to and is generally insensitive to rapamycin and has been shown to signal independently of TORC1. TORC2 is believed to mediate cell proliferation and cell survival through phosphorylation of its substrates, which include Akt, serum-, and glucocorticoid-induced protein kinase (SGK), and protein kinase C (Sparks \& Guertin 2010).

$\mathrm{PI} 3 \mathrm{~K} / \mathrm{Akt} / \mathrm{mTOR}$ signaling is negatively regulated by the tumor suppressor phosphatases and tensin homolog (PTEN) and inositol polyphosphate-4-phosphatase, type II (INPP4B), which convert $\mathrm{PI}(3,4,5) \mathrm{P}_{3}$ to $\mathrm{PI}(4,5) \mathrm{P}_{2}$ and $\mathrm{PI}(3,4)_{2}$ to $\mathrm{PI}(3) \mathrm{P}$ respectively. TORC1-activated S6K has also been shown to negatively regulate PI3K/Akt/mTOR by phosphorylating TORC2, resulting in a reduction in TORC2-dependent S473 phosphorylation of Akt (Dibble et al. 2009). In addition, S6K negatively regulates RTK signaling and hence PI3K/Akt/mTOR and RAS/RAF/MEK signaling by phosphorylating and causing the degradation of insulin receptor substrate 1 (IRS-1; O'Reilly et al. 2006, Carracedo et al. 2008, Rodrik-Outmezguine et al. 2011).

\section{The PI3K/Akt/mTOR signaling pathway in prostate cancer}

In prostate cancer, alterations of components of the PI3K/Akt/mTOR pathway, including mutation, altered expression, and copy number alterations, have been reported in $42 \%$ of primary prostate tumors and $100 \%$ of metastatic tumors (Taylor et al. 2010). These alterations lead to increased PI3K/Akt/mTOR signaling activity, and the constellation of abnormalities include decreased expression of the inhibitory phosphatases PTEN, INPP4B, and $\mathrm{PH}$ and leucine-rich repeat protein phosphatase (PHLPP; a negative regulator of Akt); activating mutations in the PI3K catalytic gene PIK3CA; and decreased expression of the PI3K regulatory genes PIK3R1 and PIK3R3 (Fig. 3). Furthermore, androgens cause the

Published by Bioscientifica Ltd. 


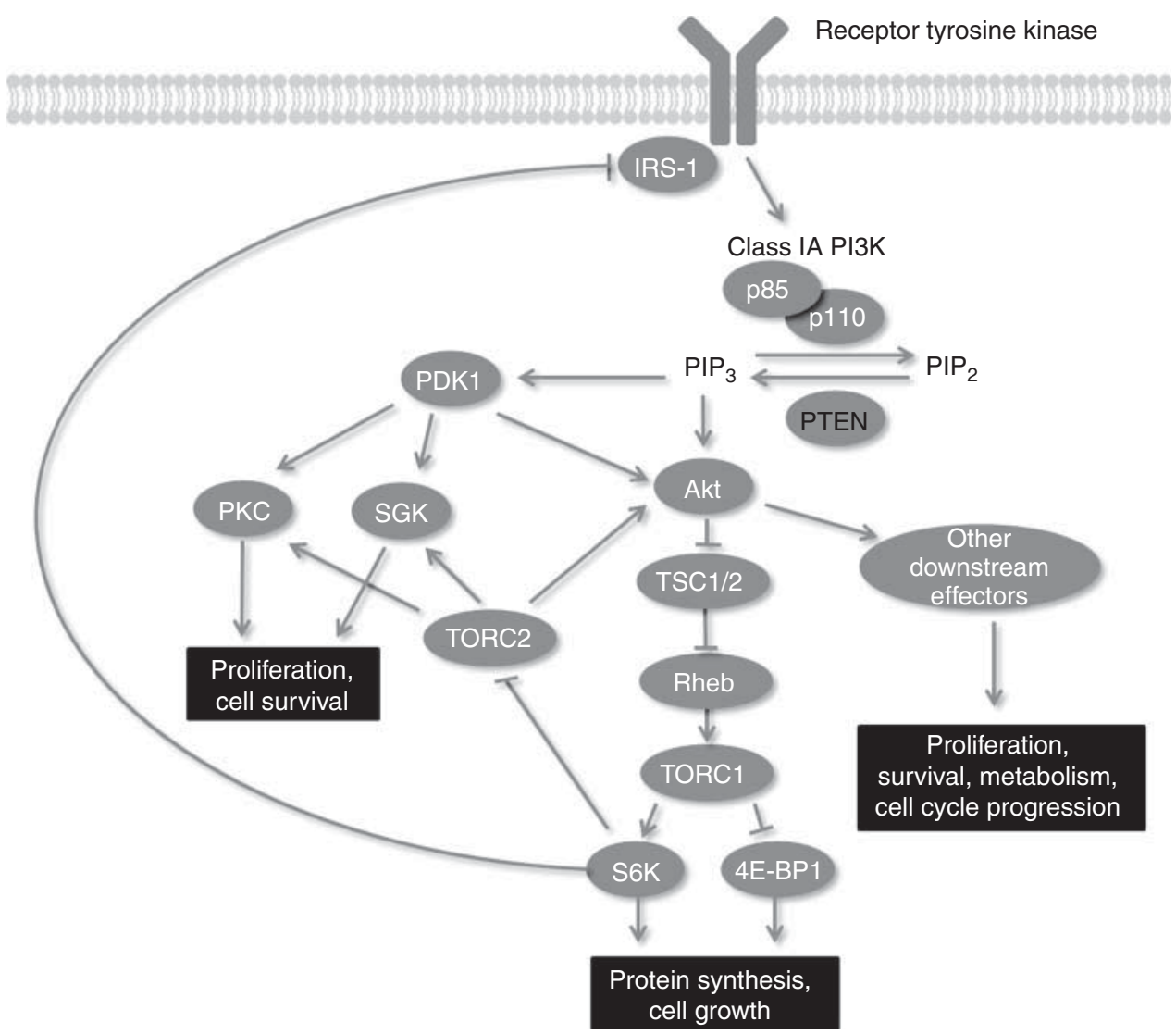

Figure 1

The PI3K/Akt/mTOR pathway. IRS-1, insulin receptor substrate 1; PDK, phosphoinositide-dependent protein kinase; $\mathrm{PI} 3 \mathrm{~K}$, phosphatidylinositol 3-kinase; PKC, protein kinase C; PTEN, phosphatase and tensin homolog; Rheb, RAS homolog enriched in the brain; S6K, S6 kinase; SGK, serum and

TORC2 complex components, rapamycin-insensitive companion of mTOR, and stress-activated protein kinase-interacting protein 1 to accumulate in the nucleus, which stimulates TORC2 to activate Akt (Fang et al. 2012). Prostate cancer development in the setting of PTEN loss requires TORC2 activity (Guertin et al. 2009). Both PTEN loss and Akt activation have been associated with poor clinical outcome (Kreisberg et al. 2004), biochemical recurrence after radical prostatectomy (Ayala et al. 2004, Bedolla et al. 2007), and resistance to radiation (Skvortsova et al. 2008) and chemotherapy (Grunwald et al. 2002, Qian et al. 2010). In addition, PTEN loss has also been shown to predict for shorter time to metastasis (Lotan et al. 2011), and castration-resistant growth has been shown to be an intrinsic property of PTEN-null prostate cancer cells, independent of cancer developmental stage (Mulholland et al. 2011). Preclinical studies suggest that the $\mathrm{PI} 3 \mathrm{~K} / \mathrm{Akt} / \mathrm{mTOR}$ pathway is important in maintaining a glucocorticoid-regulated kinase; TORC, target of rapamycin complex; TSC, tuberous sclerosis protein; $4 \mathrm{E}-\mathrm{BP} 1$, eukaryotic initiation factor 4E-binding protein 1.

cancer stem cell population (Dubrovska et al. 2009) and is involved in epithelial-to-mesenchymal transition (EMT) in prostate cancer cells (Lim et al. 2011, Mulholland et al. 2012). Furthermore, the loss of PTEN results in upregulation of the transforming growth factor $\beta / S M A D 4$ pathway and subsequent silencing or loss of SMAD4 may contribute to the metastatic propensity of PTEN-null prostate cancer (Ding et al. 2011). Taken together, these data suggest that the PI3K/Akt/mTOR pathway is fundamental to the metastatic potential of prostate cancer and provide a strong rationale for targeting the PI3K/Akt/mTOR pathway in this disease.

\section{Cross talk with other signaling pathways}

In addition to its direct effects, the PI3K/Akt/mTOR pathway contributes to prostate cancer development and progression through interacting with other cell signaling 


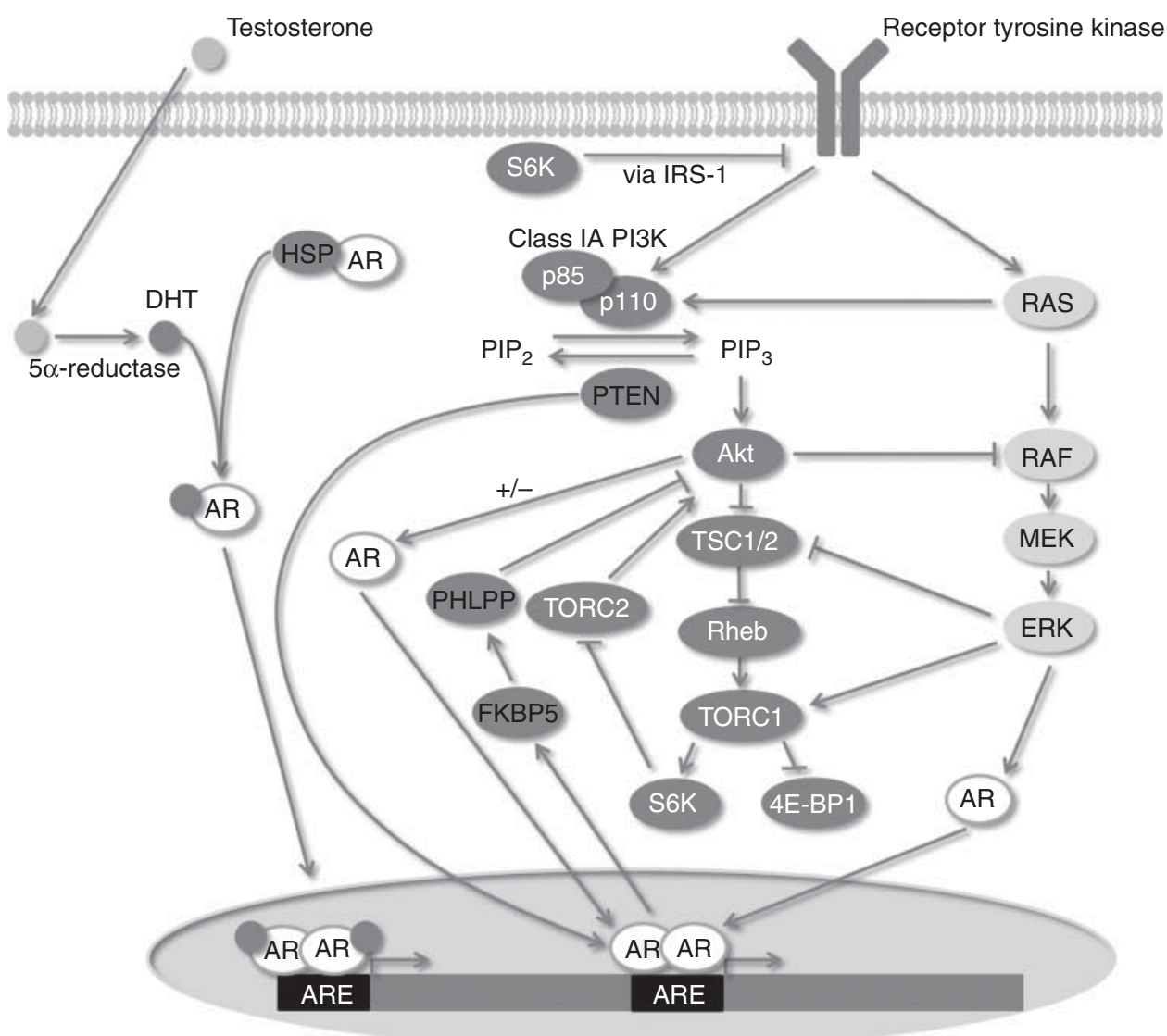

Figure 2

The PI3K/Akt/mTOR pathway and cross talk with the AR signaling and RAS/RAF/MEK pathways. AR, androgen receptor; ARE, androgenresponsive element; $\mathrm{DHT}$, dihydrotestosterone; $4 \mathrm{E}-\mathrm{BP} 1$, eukaryotic initiation factor $4 \mathrm{E}$-binding protein 1 ; ERK, extracellular signal-related kinase; FKBP5, FK506-binding protein 5; HSP, heat-shock proteins; IRS-1, insulin receptor substrate 1; MEK, mitogen-activated protein/ERK kinase; PHLPP, PH and leucine-rich repeat phosphatase; PI3K, phosphatidylinositol 3-kinase; PTEN, phosphatase and tensin homolog; RAS, rat sarcoma

pathways important for cellular survival, growth, and differentiation, including the AR and the RAS/RAF/MEK signaling pathways (Fig. 2).

AR signaling is critical for the development and function of the normal prostate gland and remains important upon neoplastic transformation, which is the basis for androgen deprivation therapy (Chen et al. 2008). Amplification of AR signaling, mutations in the ligandbinding domain of AR, and induction of AR splice variants have been shown to promote castration-resistant progression (Watson et al. 2010, Mostaghel et al. 2011). In addition, prostate cancer cells can develop the machinery necessary for autocrine androgen production that is capable of activating AR in the face of low serum testosterone levels (Montgomery et al. 2008). These data oncogene; Rheb, RAS homolog enriched in the brain; S6K, S6 kinase; TSC, tuberous sclerosis protein; TORC, target of rapamycin complex; $+I-$, Akt activity can both enhance and suppress AR signaling. Possible mechanisms of Akt-mediated regulation of AR activity include direct phosphorylation of AR (Wen et al. 2000, Lin et al. 2001); Akt-mediated regulation of a variety of transcription factors, including $\mathrm{FOXO3a}$, and NF- $\kappa \beta$; and Akt-mediated regulation of $\beta$-catenin via GSK3 $\beta$ (Li et al. 2008, Sarker et al. 2009).

support the importance of active hormonal signaling in CRPC progression and explain the success of novel androgen synthesis inhibitors, such as abiraterone acetate, and AR antagonists, such as enzalutamide, even in the castrate-resistant state. However, responses to abiraterone acetate and enzalutamide are not universal, and when present, are often short-lived, lasting $\sim 6-8$ months in the post-docetaxel CRPC setting (de Bono et al. 2011, Scher et al. 2012).

The PI3K/Akt/mTOR and AR signaling pathways have recently been shown to regulate each other through complex reciprocal feedback mechanisms (Fig. 2; Wen et al. 2000, Lin et al. 2001, Li et al. 2008, Sarker et al. 2009, Carver et al. 2011, Mulholland et al. 2011). PI3K/Akt/ mTOR signaling inhibits AR signaling via feedback

Published by Bioscientifica Ltd 


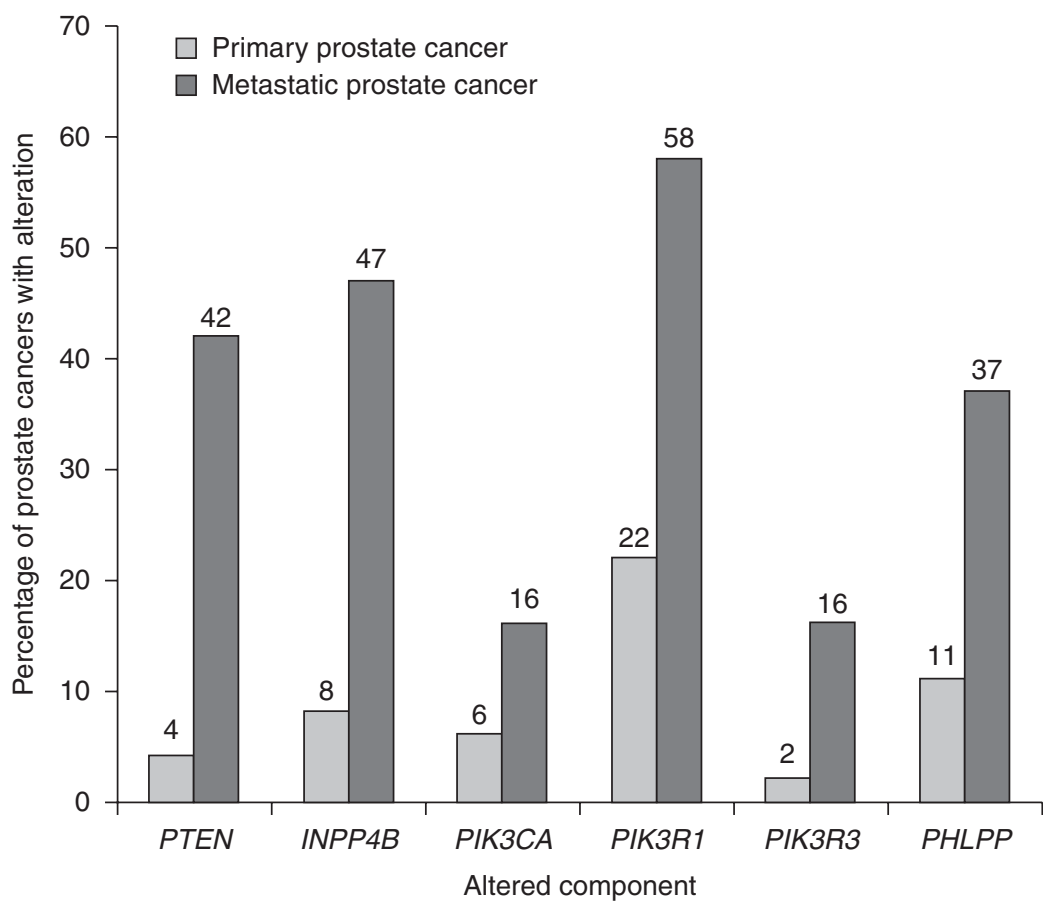

Figure 3

Alteration of the PI3K/Akt/mTOR pathway in primary and metastatic prostate cancer (Taylor et al. 2010). INPP4B, inositol polyphosphate-4-phosphatase, type II; PHLPP, PH domain and leucine-rich repeat protein phosphatases; PTEN, phosphatase and tensin homolog.

inhibition of human epidermal growth factor $2 / 3$ (HER2/3) kinases, which have been shown to promote AR stability and transcriptional activity (Carver et al. 2011). In addition, PTEN increases the transcriptional activity of AR by negatively regulating the expression of the transcription factors Egr1 and c-JUN, which inhibit AR-targeted gene expression (Mulholland et al. 2011). Meanwhile, AR signaling downregulates PI3K/Akt/mTOR signaling through FK506-binding protein-5 (FKBP-5)mediated stabilization of the Akt phosphatase PHLPP (Carver et al. 2011). Activation of the PI3K/Akt/mTOR pathway as a result of treatments targeting AR signaling or due to PTEN loss may, therefore, enable prostate cancer cells to survive and proliferate in androgen-reduced conditions. Conversely, PTEN controls the transcription of NKX3.1, which negatively regulates the AR promoter and reduces AR pathway signaling. When PTEN is lost, this brake on AR signaling is also lost (Lei et al. 2006). Therefore, inhibition of the PI3K/Akt/mTOR pathway may lead to a compensatory increase in AR activity and may promote prostate cancer progression and development of resistance to single-agent PI3K pathway inhibitor therapy. This concept of reciprocal inhibition is further supported by the recent finding that use of antiandrogens for chemoprevention actually accelerates progression to invasive prostate cancer in a PTEN-null mouse model (Jia et al. 2013). Thus, blockade of both the AR and PI3K/Akt/mTOR signaling pathways may lead to more effective anticancer activity than targeting either pathway alone.

The RAS/RAF/MEK pathway is also involved in extensive cross talk with the PI3K/Akt/mTOR pathway (Fig. 2), and activation of this pathway has been associated with decreased sensitivity to PI3K/Akt/mTOR pathway inhibitors (Ihle et al. 2009). Recently, a study of prostate cancer tissue microarrays found that the RAS/RAF/MEK pathway was significantly elevated in both primary and metastatic lesions (Mulholland et al. 2012). In murine models, PTEN deletion results in the development of prostate cancer (Wang et al. 2003); however, the combination of PTEN deletion and RAS activation significantly accelerated prostate cancer progression caused by PTEN loss, and this was accompanied by EMT and macrometastasis (Mulholland et al. 2012). Furthermore, inhibition of the RAS/RAF/MEK pathway with a MEK inhibitor (PD325901) significantly reduced metastatic progression initiated by PTEN-deficient and KRAS-activated stem/ progenitor cells (Mulholland et al. 2012). Thus, cross talk

Published by Bioscientifica Ltd 
between the PI3K/Akt/mTOR pathway and the RAS/RAF/ MEK pathway in prostate cancer is likely clinically important in promoting metastasis.

RTKs, which activate both the PI3K/Akt/mTOR and the RAS/RAF/MEK pathways, are in turn negatively regulated by TORC1 activity; inhibition of TORC1 leads to a relief of an inhibitory signal from S6 to IRS-1, a receptor substrate for multiple cell surface receptors, such as insulin and IGF, HER2/3 and epidermal growth factor receptor (EGFR), and others (O'Reilly et al. 2006, Carver et al. 2011, Rodrik-Outmezguine et al. 2011). Relief of this feedback inhibition with single-agent rapamycin analogs may lead to rapid compensatory PI3K and Akt re-activation and limit the pharmacodynamics and clinical impact of these agents on tumor cell survival and invasion/metastasis (Rodrik-Outmezguine et al. 2011). Combined inhibition of cell surface receptors with TORC1 inhibitors has demonstrated an ability to overcome this feedback loop and is an area of ongoing investigation. Whether combination therapy with PI3K, AR, cell surface receptor, and/or RAS/RAF/MEK pathway inhibition is needed for optimal therapy in preclinical or clinical prostate cancer is not known at this time.

\section{Inhibiting the PI3K/Akt/mTOR pathway in prostate cancer}

Given the importance of the PI3K/Akt/mTOR pathway in integrating cell survival signals and the high prevalence of activating PI3K/Akt/mTOR pathway alterations in prostate cancer, inhibitors of this pathway have great potential to deliver clinical benefit for men with CRPC. There are a number of agents under investigation and in the clinic today that target the PI3K/Akt/mTOR pathway for the treatment of advanced cancers. Many of these are oral agents, some are administered intravenously, and all are associated with some degree of reversible metabolic toxicity such as hyperglycemia and hyperlipidemia (Busaidy et al. 2012). Inhibition of various components of the PI3K/Akt/mTOR pathway results in differing side effect and efficacy profiles, as discussed below.

\section{mTOR inhibitors: early clinical experience}

The allosteric TORC1 inhibitor rapamycin and its analogs (rapalogs), including everolimus, temsirolimus, and ridaforolimus, were the first inhibitors of the PI3K/Akt/mTOR pathway to enter clinical development. In preclinical studies, these early TORC1 inhibitors were shown to revert prostatic intraepithelial neoplasia in a mouse model overexpressing human Akt (Majumder et al. 2004) and to inhibit tumor growth in mouse xenograft models derived from $P T E N^{-/-}$PC-3 and $P T E N^{+/-}$DU145 cells (Wu et al. 2005). Despite these promising preclinical results and the success of rapalogs in the treatment of patients with metastatic renal cell carcinoma (Motzer et al. 2008, Kwitkowski et al. 2010) and pancreatic neuroendocrine tumors (Yao et al. 2011), the clinical experience of singleagent TORC1 inhibition in men with CRPC has been disappointing, with few (if any) clinical, radiographic, or prostate-specific antigen (PSA) responses, and a relatively short time to clinical progression (2-3 months; Amato et al. 2008, George et al. 2008, Templeton et al. 2011). Moreover, in a pharmacodynamic study of rapamycin in men with intermediate- to high-risk localized prostate cancer treated before radical prostatectomy, inhibition of the TORC1 target phospho-S6 was clearly demonstrated, but no significant effects on tumor cell proliferation (Ki-67), induction of apoptosis (caspase-3 cleavage), posttreatment tumor grade or stage, or PSA levels were observed (Armstrong et al. 2010). In addition, upregulation of Akt activity was seen in some men, but again changes in Akt activity after rapamycin exposure did not correlate with any indication of treatment benefit. These data, which are supported by our observations with the TORC1 inhibitor temsirolimus in a phase II trial of men with CRPC (NCT00887640) and a single-arm study of oral rapamycin (Amato et al. 2008), establish that rapalogs are able to inhibit the intended target (TORC1) in human prostate cancer at standard dosing but do not elicit striking pathological or clinical benefits as single agents.

Several explanations likely underlie the lack of clinical activity of rapamycin analogs in advanced prostate cancer. One reason is that rapalogs do not inhibit TORC2, which activates Akt in prostate cancer cells (Sarbassov et al. 2006). This, combined with loss of S6K-mediated negative regulation of TORC2 as a result of TORC1 inhibition (Dibble et al. 2009), may therefore explain the increases in Akt activity and lack of clinical activity seen with rapalogs in prostate cancer and suggests that combined TORC1/2 inhibition may be required. In addition, paradoxical activation of cell surface receptors (such as HER2/3), AR, or RAS pathway, as discussed earlier, may explain treatment resistance. Finally, other TORC1 downstream targets, such as the eukaryotic initiation factor 4E-BP1 and the eukaryotic translation initiation factor $4 \mathrm{E}$ (eIF-4E) complex, are not inhibited by these agents (Furic et al. 2010). 4E-BP1 regulates translation elongation of a discrete set of key oncogenic proteins related to de-differentiation and EMT and has been directly

Published by Bioscientifica Ltd. 
implicated in prostate cancer invasion and metastatic progression. Inhibition of 4E-BP1 has been reported with TORC1/2 kinase inhibitors and more upstream pathway inhibitors (Hsieh et al. 2012). Thus, while first-generation signaling inhibitors of TORC1 left this key translational oncogenic apparatus unsuppressed, second-generation TORC1/2 kinase inhibitors and further upstream PI3K pathway inhibitors may have a greater clinical impact.

\section{Dual TORC1/2 inhibitors}

By inhibiting both mTOR complexes, ATP-competitive dual TORC1/2 inhibitors should prevent the upregulation of Akt seen with rapalogs and lead to more complete suppression of the PI3K/Akt/mTOR pathway. Indeed, these agents have been shown to possess a greater ability to inhibit 4E-BP1 and protein synthesis and induce cell cycle arrest in several cell lines (Sparks \& Guertin 2010). Furthermore, in prostate cancer, the TORC1/2 inhibitor MLN0128 was superior to TORC1 inhibition alone, as it not only prevented prostate cancer invasion and metastasis but also induced apoptosis (Hsieh et al. 2012). This improved efficacy may not simply reflect the ability of dual TORC1/2 inhibitors to inhibit both TORC1 and TORC2 but may be due to more complete inhibition of TORC1 downstream effectors, such as the eIF-4E complex. A possible caveat to improved inhibition of TORC1 is that, even in the context of TORC2 inhibition, the loss of S6K-mediated negative feedback may still activate PI3K/ Akt/mTOR signaling via activation of RTKs. Supporting this view is the fact that at low concentrations (50 nM), the TORC1/2 inhibitor Torin was shown to activate Akt, and only at high concentrations $(250 \mathrm{nM})$ did Torin inhibit TORC2 (Peterson et al. 2009). Despite these concerns, the TORC1/2 inhibitors MLN0128, AZD2014, DS-3078a, and OSI-027 are currently in early-stage clinical trials in solid tumors, including prostate cancer.

\section{Pan-PI3K inhibitors}

Pan-PI3K inhibitors target the catalytic subunits of all three isoforms of class IA PI3Ks (p110 $\alpha, \beta$, and $\delta$ ) and the class IB PI3K catalytic subunit p110 $\gamma$. In preclinical studies, an early pan-PI3K inhibitor, LY294002, was shown to suppress cell invasion and motility in the highly metastatic androgen-independent Dunning rat prostate cancer MLL cell line; however, this agent lacked favorable pharmacological properties and had many off-target effects (Prawettongsopon et al. 2009). Meanwhile, the PI3K inhibitors GDC-0941 and BKM120, which have improved pharmacological properties, have been shown to inhibit proliferation in the androgen-independent metastatic PC-3 cell line and halt tumor growth in xenograft mice harboring PC-3M cells (Raynaud et al. 2009, Maira et al. 2012b).

The largest clinical experience to date of a pan-PI3K inhibitor is a phase I first-in-man study of BKM120, which defined the maximum tolerated dose of BKM120 as $100 \mathrm{mg} /$ day. Overall, treatment with BKM120 was well tolerated, and treatment-related adverse events included rash, hyperglycemia, diarrhea, anorexia, mood alteration (37\% each), nausea (31\%), and fatigue (26\%). Of the 31 evaluable patients, one patient (3\%) had a confirmed partial response, 16 patients (52\%) had stable disease for at least 6 weeks, and seven patients (23\%), including one patient with prostate cancer, remained on study for 8 months (Bendell et al. 2012). Neuropsychiatric adverse events, including reversible and generally mild-to-moderate mood alterations and depression were seen with BKM120 treatment and are thought to reflect the ability of BKM120 to cross the blood-brain barrier and inhibit the PI3K/Akt/mTOR pathway in the brain (Maira et al. 2012a, Nanni et al. 2012). In support of this, low/dysfunctional $\mathrm{PI} 3 \mathrm{~K} / \mathrm{Akt} / \mathrm{mTOR}$ signaling has been shown to reduce the concentration of the neurotransmitters GABA and serotonin in anxiety-related brain regions such as the amygdala and has been linked to anxiety and depression (Ackermann et al. 2008). Mood alterations observed in this phase I study of BKM120, therefore, highlight the need for close monitoring for psychiatric symptoms in patients treated with PI3K/Akt/mTOR inhibitors. Other PI3K inhibitors including GDC-0941, SAR245408, and the irreversible PI3K inhibitor PX-866 have also been shown to be well tolerated and have demonstrated signs of preliminary activity in patients with advanced solid tumors (Edelman et al. 2010, Jimeno et al. 2010, Von Hoff et al. 2010). Common adverse events included nausea, diarrhea, vomiting, fatigue, decreased appetite, dysgeusia, and rash with GDC-0941 (Von Hoff et al. 2010); skin rash with SAR245408 (Edelman et al. 2010); and nausea, vomiting, and diarrhea with PX-866 (Jimeno et al. 2010). BKM120 (as a single agent and in combination with abiraterone acetate) and PX-866 are currently under investigation in metastatic CRPC (Table 1). A limitation of single-agent PI3K pathway inhibition, as with singleagent TORC1/2 inhibition, is the possible relief of reciprocal feedback pathways that inhibit cell surface receptor, AR, and RAS pathway activation (Carver et al. 2011, Rodrik-Outmezguine et al. 2011). Thus, careful clinical pharmacodynamic studies are needed to

Published by Bioscientifica Ltd. 
Table $1 \mathrm{PISK} / \mathrm{Akt} / \mathrm{mTOR}$ pathway inhibitors currently in clinical development in advanced prostate cancer.

\begin{tabular}{|c|c|c|c|c|c|}
\hline Agent & Manufacturer & Phase & Regimen & Population & Registry \\
\hline \multicolumn{6}{|l|}{$\begin{array}{l}\text { Pan-PI3K } \\
\text { inhibitors }\end{array}$} \\
\hline \multirow[t]{3}{*}{ BKM120 } & Novartis & 1 & $\begin{array}{l}+ \text { Abiraterone acetate } \\
\text { (CYP17A1 inhibitor) }\end{array}$ & $\begin{array}{l}\text { CRPC that has progressed on } \\
\text { abiraterone acetate }\end{array}$ & NCT01634061 \\
\hline & & I & + Abiraterone acetate & Metastatic CRPC & NCT01741753 \\
\hline & & II & Monotherapy & $\begin{array}{l}\text { Metastatic CRPC that has } \\
\text { progressed following ADT } \\
\text { and chemotherapy }\end{array}$ & NCT01385293 \\
\hline PX866 & Oncothyreon & II & Monotherapy & $\begin{array}{l}\text { Metastatic CRPC that has } \\
\text { progressed following ADT }\end{array}$ & NCT01331083 \\
\hline \multicolumn{6}{|l|}{$\begin{array}{l}\text { Dual PI3K/mTOR } \\
\text { inhibitors }\end{array}$} \\
\hline BEZ235 & Novartis & I & $\begin{array}{l}+ \text { Abiraterone acetate } \\
\text { (CYP17A1 inhibitor) }\end{array}$ & $\begin{array}{l}\text { CRPC that has progressed on } \\
\text { abiraterone acetate }\end{array}$ & NCT01634061 \\
\hline GDC-0980 & Genentech & II & + Abiraterone acetate & $\begin{array}{l}\text { CRPC previously treated with } \\
\text { docetaxel-based } \\
\text { chemotherapy }\end{array}$ & NCT01485861 \\
\hline \multicolumn{6}{|l|}{ Akt inhibitors } \\
\hline MK2206 & Merck & II & $\begin{array}{l}+ \text { Bicalutamide } \\
\text { (anti-androgen) }\end{array}$ & $\begin{array}{l}\text { Patients with rising PSA at } \\
\text { high risk of progression } \\
\text { after primary therapy }\end{array}$ & NCT01251861 \\
\hline GDC-0068 & Genentech & II & $\begin{array}{l}+ \text { Abiraterone acetate and } \\
\text { prednisone (glucocorticoid) }\end{array}$ & $\begin{array}{l}\text { Metastatic or advanced prostate } \\
\text { adenocarcinoma that has } \\
\text { progressed on one hormonal } \\
\text { treatment }\end{array}$ & NCT01485861 \\
\hline \multicolumn{6}{|l|}{ TORC1 inhibitors } \\
\hline \multirow[t]{6}{*}{ Everolimus } & Novartis & II & Monotherapy & Metastatic CRPC & NCT00629525 \\
\hline & & II & + Pasireotide (somatostatin) & Chemotherapy-naïve CRPC & NCT01313559 \\
\hline & & $\mathrm{I} / \mathrm{II}$ & $\begin{array}{l}+ \text { Docetaxel, bevacizumab } \\
\text { (VEGF inhibitor) }\end{array}$ & Metastatic CRPC & NCT00574769 \\
\hline & & $\mathrm{I} / \mathrm{II}$ & + Docetaxel & Metastatic CRPC & NCT00459186 \\
\hline & & II & $\begin{array}{l}+ \text { Carboplatin, everolimus, } \\
\text { and prednisone }\end{array}$ & $\begin{array}{l}\text { Metastatic CRPC cancer that has } \\
\text { progressed after docetaxel }\end{array}$ & NCT01051570 \\
\hline & & II & + Bicalutamide & $\begin{array}{l}\text { Recurrent or metastatic CRPC } \\
\text { after first-line ADT }\end{array}$ & NCT00814788 \\
\hline \multirow[t]{6}{*}{ Temsirolimus } & Wyeth & $\mathrm{I} / \mathrm{II}$ & $\begin{array}{l}+ \text { Temsirolimus (mTOR } \\
\text { inhibitor) and bevacizumab }\end{array}$ & $\begin{array}{l}\text { Chemotherapy-treated } \\
\text { metastatic CRPC }\end{array}$ & NCT01083368 \\
\hline & & II & Monotherapy & $\begin{array}{l}\text { Chemotherapy-treated } \\
\text { metastatic CRPC }\end{array}$ & NCT00887640 \\
\hline & & II & Monotherapy & Chemotherapy-naïve CRPC & NCT00919035 \\
\hline & & $\mathrm{I}$ & + Vorinostat (HDAC inhibitor) & Metastatic CRPC & NCT01174199 \\
\hline & & $\mathrm{I} / \mathrm{II}$ & + Docetaxel & CRPC receiving first-line docetaxel & NCT01206036 \\
\hline & & $\mathrm{I} / \mathrm{II}$ & + Cixutumumab & Metastatic CRPC & NCT01026623 \\
\hline
\end{tabular}

ADT, androgen deprivation therapy; CRPC, castration-resistant prostate cancer; HDAC, histone deacetylase inhibitor; MEK, mitogen-activated protein/extracellular signal-related kinase; mTORC, mammalian target of rapamycin complex; VEGF, vascular endothelial growth factor.

determine whether resistance mechanisms observed preclinically (Carver et al. 2011) are also clinically relevant. Understanding such resistance mechanisms will aid in the selection of optimal partners for combination.

\section{Isoform-specific PI3K inhibitors}

As each isoform of p110 has a distinct role (Jia et al. 2009), targeting the p110 isoform involved in a particular cancer may therefore have the advantage of an improved safety profile. PIK3CA, which encodes $\mathrm{p} 110 \alpha$, is mutated in $6 \%$ of primary and $16 \%$ of metastatic prostate cancers (Taylor et al. 2010), and the PIK3CA H1047R mutation has been shown to be predictive of response to pan-PI3K inhibitors (Janku et al. 2012), suggesting that p110 $\alpha$-specific inhibition may be effective treatment in tumors with activating PIK3CA mutations. Indeed, both the $\mathrm{p} 110 \alpha$ isoform-specific inhibitors BYL719 (Fritsch et al. 2012) and the MLN1117 (Jessen et al. 2011) have demonstrated antitumor activity in tumor cell lines with PIK3CA mutations. However, in a PTEN-null prostate tumor model, ablation of $\mathrm{p} 110 \beta$, but not $\mathrm{p} 110 \alpha$, impeded 
tumorigenesis (Jia et al. 2008). Similarly, the activity of MLN1117 was much lower in cells with PTEN deficiency (Jessen et al. 2011). Therefore, $\beta$-specific inhibitors such as GSK2636771 are in early-stage development, and it is likely that the efficacy of these inhibitors will depend on whether tumorigenesis is driven by PIK3CA mutation or loss of PTEN. A potential limitation of isoform-specific inhibition is the possibility of functional redundancy between isoforms. In PC-3 cells, for example, the combination of an $\alpha / \delta$ PI3K inhibitor with a $\beta$-specific inhibitor (TGX-221) resulted in increased suppression of the pathway compared with inhibition of $\alpha / \delta$ and $\beta$ isoforms independently (Edgar et al. 2010).

\section{Dual PI3K/TORC1/2 inhibitors}

Dual PI3K/TORC1/2 inhibitors are ATP-competitive inhibitors that target all four p110 isoforms and both mTOR complexes and should lead to a more complete blockade of the PI3K/Akt/mTOR pathway. Indeed, the dual PI3K/TORC1/2 inhibitors GDC-0980 and BEZ235 inhibited PI3K/Akt/mTOR signaling and induced G1 arrest across a broad panel of cancer cell lines (Maira et al. 2008, Wallin et al. 2011). Greatest sensitivity to GDC-0981 was observed in breast, prostate, and lung cancer cells, and in contrast to the TORC1 inhibitors, GDC-0980 was also shown to induce apoptosis in cells with direct pathway activation via PIK3CA mutation or PTEN loss (Wallin et al. 2011). Furthermore, the effects of the dual PI3K/TORC1/2 inhibitor PI-101 on PC-3 cells were enhanced through combination with rapamycin or everolimus, as indicated by phosphorylated-Akt levels in vitro and tumor growth in vivo, suggesting that combining competitive and allosteric inhibition leads to improved suppression of the pathway (Mazzoletti et al. 2011). In the clinic, GDC-0980 and BEZ235 have been well tolerated in patients with solid tumors, with common adverse events including nausea, vomiting, diarrhea, and fatigue (Burris et al. 2010, Wagner et al. 2011). With BEZ235, partial responses were observed in two patients (4\%), and 14/51 (27\%) of evaluable patients had stable disease for at least 4 months (Burris et al. 2010). Issues surrounding the formulation of BEZ235 have delayed drug development to date for this agent, which remains in phase I testing at present. Phase I/II clinical trials of GDC-0980 and BEZ235 are ongoing in metastatic CRPC, alone and in combination with abiraterone acetate, as is a combination of BEZ235 with everolimus in advanced solid tumors (Table 1 ).

\section{Akt inhibitors}

As an important central regulator of $\mathrm{PI} 3 \mathrm{~K} / \mathrm{Akt} / \mathrm{mTOR}$ signaling, Akt has been a long-standing focus for therapeutic inhibition, but due to the homology between Akt and other kinases, Akt-selective drug development has been difficult. Preclinical studies with the allosteric Akt inhibitor perifosine have shown that it can induce cell cycle arrest and cell death in both PC-3 (Floryk \& Thompson 2008) and PTEN-deficient CaP cells (Festuccia et al. 2008). However, despite a good safety profile in early clinical trials (the most common adverse events were diarrhea, nausea, fatigue, and vomiting), no evidence of radiographic or PSA response ( $>50 \%$ decline in PSA) was observed in patients with CRPC (Posadas et al. 2005, Chee et al. 2007). More recently, ATP-competitive selective Akt inhibitors such as GSK690693 and GDC-0068 have demonstrated antitumor activity in prostate cancer xenograft models (Rhodes et al. 2008, Lin 2011). It remains to be seen whether the ATP-competitive Akt inhibitors will have clinical benefit, but a lack of clinical efficacy of perifosine suggests that Akt-independent PI3K signaling may be important in prostate cancer. For example, it has been shown that tumors with PIK3CA mutations rely on the Akt-independent target SGK3 for tumorigenesis (Vasudevan et al. 2009), suggesting that targeting of PI3K may be more effective than targeting Akt in some tumors. Alternatively, dosing of perifosine may not have led to sufficient inhibition of key Akt effectors, such as the eIF-4E complex. These results suggest the need for careful pharmacokinetic-pharmacodynamic studies in patients to determine optimal dosing and resistance mechanisms.

\section{Combining PI3K/Akt/mTOR pathway inhibitors with other therapies}

Similar to complex infectious diseases such as tuberculosis and HIV/AIDS, in which combination approaches revolutionized therapy and transformed a life-threatening illness into a curable or controllable illness with an excellent long-term prognosis, combination therapies, based on knowledge of feedback resistance pathways inherent to the cancer cell and the tumor microenvironment that are activated during single-agent therapy, are an emerging and necessary step in oncology (Glickman \& Sawyers 2012). With PI3K/Akt/mTOR pathway inhibitors, use of combination partners may be particularly important due to the large degree of cross talk and reciprocal feedback regulation between the PI3K/Akt/mTOR pathway and other signaling pathways highlighted earlier.

Published by Bioscientifica Ltd. 
Combination strategies in preclinical models have turned previously cytostatic activity into cytocidal activity and more durable remissions.

\section{Combination with anti-androgen therapy}

The clinical results of the aromatase inhibitor exemestane in combination with everolimus in metastatic estrogen receptor/progesterone receptor-positive breast cancer are testament to the power of rationale combination approaches (Baselga et al. 2012). Similar to the AR signaling pathway in prostate cancer, in breast cancer, there is evidence that the estrogen receptor signaling pathway interacts with the PI3K/Akt/mTOR pathway. Specifically, phosphorylation of the estrogen receptor by S6K1, downstream of TORC1, leads to ligand-independent signaling and may be a mechanism of resistance to endocrine therapy (Yamnik et al. 2009). In a large phase III study of patients with breast cancer who had progressed on an aromatase inhibitor, the addition of the mTOR inhibitor everolimus to exemestane resulted in a 6-month improvement in progression-free survival (Baselga et al. 2012). Given the known cross talk between the AR and PI3K/Akt/mTOR pathways (Carver et al. 2011), this study provides a rationale for combined AR and PI3K/Akt/mTOR targeted therapy and suggests that a clinical benefit with a combination approach may be possible for patients with prostate cancer as well. In support of this, combined targeting of the AR and PI3K/Akt/mTOR pathways with the PI3K inhibitor BEZ235 and the AR signaling inhibitor enzalutamide in PTEN-deficient cell lines resulted in a profound increase in apoptotic cell death, while only modest cytostatic activity was observed with each agent individually (Carver et al. 2011). Furthermore, combination of the mTOR inhibitor rapamycin with either chemical or surgical castration resulted in additive antitumor effects in a PTEN-deficient prostate cancer mouse model (Zhang et al. 2009), and the addition of everolimus to bicalutamide in a xenograft model harboring LN-CaP cells significantly reduced tumor growth rates compared with bicalutamide alone (Schayowitz et al. 2010). However, clinical results of the combination of the anti-androgen bicalutamide with the mTOR inhibitor everolimus in patients with CRPC have been conflicting. In a phase II trial, low activity was observed: two (6\%) patients had a confirmed PSA response ( $\geq 50 \%$ reduction in PSA) and median time to progression was 8.7 weeks (Nakabayashi et al. 2012). Meanwhile, in a phase I/II study, partial responses ( $\geq 30 \%$ decline in PSA) were observed in nine patients $(69 \%)$ compared with only one patient $(20 \%)$ in the placebo-plus-bicalutamide arm (Pan et al. 2012). These variable results may be due to incomplete suppression of the PI3K/Akt/mTOR pathway with everolimus or due to inadequate activity of bicalutamide in patients with CRPC who have amplification of AR in their tumors (Chen et al. 2004). Further evaluation of four patients who responded to treatment vs four patients who did not revealed that responders had significantly elevated HER3 levels (Pan et al. 2012), and HER3 levels are now being investigated as a predictive biomarker for response to everolimus in hormone-treated prostate cancer patients. Combination studies of PI3K/Akt/mTOR pathway inhibitors with novel androgen synthesis inhibitors, such as abiraterone acetate or orteronel, or with novel anti-androgens, such as enzalutamide or ARN-509, may be more effective and are eagerly awaited. Currently, there are phase II studies investigating the combination of BKM120 and BEZ235 with abiraterone acetate (Table 1).

\section{Combination with chemotherapy}

Activation of the PI3K/Akt/mTOR pathway has recently been implicated in resistance to docetaxel (Qian et al. 2010), and combining PI3K/Akt/mTOR pathway inhibitors with docetaxel has demonstrated enhanced activity in a variety of preclinical models (Morgan et al. 2008, Fung et al. 2009, Dubrovska et al. 2010, Qian et al. 2010, Maira et al. 2012b, Morikawa et al. 2012). The enhanced efficacy of BEZ235 with docetaxel was shown to be a result of BEZ235induced reduction of CD133+/CD44+ tumor progenitor cells, and docetaxel-induced reduction of the tumor bulk, which resulted in near complete tumor regression in a mouse prostate cancer xenograft model (Dubrovska et al. 2010). Phase I/II clinical trials of everolimus or temsirolimus in combination with docetaxel in CRPC have been completed and results are anticipated shortly. Phase I trials of BKM120 or GDC-0068 in combination with docetaxel in advanced solid tumors are ongoing.

\section{Combination with MEK inhibitors}

As activation of the RAS/RAF/MEK pathway has been implicated in conferring resistance to PI3K/Akt/mTOR pathway inhibition (Ihle et al. 2009), and significant activation of this pathway has been observed in both primary and metastatic prostate cancer (Mulholland et al. 2012), the combination of PI3K/Akt/mTOR inhibitors with inhibitors of the RAS/RAF/MEK pathway is a rationale approach. The combination of the mTOR inhibitor rapamycin with the MEK inhibitor PD325901 resulted in

Published by Bioscientifica Ltd 
synergistic growth inhibition in the androgen-responsive cell lines CWR22Rv1 (Gioeli et al. 2011) and CASP 2.1 (Kinkade et al. 2008) and the androgen-independent cell line CASP 1.1 (Kinkade et al. 2008). While in vivo, the combination displayed potent antitumorigenic activity in a mouse model of CRPC (Gioeli et al. 2011). In a phase Ib study in patients with advanced solid tumors, the combination of the MEK inhibitor GDC-0973 and the PI3K inhibitor GDC-0941 was shown to be well tolerated with a safety profile similar to that observed with either agent alone. Furthermore, decreases in RECIST-measurable target lesions were observed in five patients: two patients with melanoma ( -75 and $-25 \%)$; one patient with prostate cancer $(-21 \%)$; and two patients with nonsmall-cell lung cancer ( -18 and $-13 \%$ ) (Shapiro et al. 2011). In preclinical prostate cancer model systems driven by PTEN loss and RAS pathway activation, the inhibition of MEK reduced invasion and metastasis and reverted EMT, suggesting the importance of RAS pathway activation to invasiveness in prostate cancer (Mulholland et al. 2012).

\section{Combination with RTK-targeted therapies}

The EGFR family tyrosine kinases, including HER2 and HER3, play a role in the growth and survival of prostate cancer cells (Renner et al. 2008), and modulation of AR function by HER2/3 signaling has been documented (Mellinghoff et al. 2004). Specifically, HER2/3 signaling is required for AR function at reduced androgen concentrations (similar to concentrations achieved during androgen deprivation therapy). Under these conditions, HER2/3 increases binding of the AR to androgen response elements in the promoters of AR target genes and stabilizes the AR protein. To date, however, EGFR and HER-targeted therapies have not demonstrated significant clinical efficacy in prostate cancer either as single agents (Ziada et al. 2004, Small et al. 2007, Pezaro et al. 2009, Sridhar et al. 2010, Whang et al. 2011) or in combination with docetaxel (Gross et al. 2007), likely in part because PTEN loss is known to mediate resistance to EGFR family tyrosine kinase inhibitors (TKIs; Mellinghoff et al. 2007), or due to the lack of upregulation of these receptors when AR is not sufficiently blocked. This, combined with the fact that mTOR inhibition relieves negative feedback inhibition on and so upregulates HER2/3 signaling (Rodrik-Outmezguine et al. 2011), provides a robust rationale for co-targeting of RTKs and the PI3K/Akt/mTOR and/or AR pathways in prostate cancer. In preclinical studies, the combination of EGFR and Akt inhibition had synergistic anticancer activity in PTEN-deficient prostate cancer cells (Festuccia et al. 2008), while the dual EGFR and vascular endothelial growth factor (VEGF) TKI AEE788 combined with the mTOR inhibitor everolimus profoundly reduced tumor-endothelium and tumor-matrix contacts and suppressed cell growth in a variety of prostate cancer cells (Wedel et al. 2011a). Moreover, the triple combination of everolimus, AEE788, and the histone deacetylase inhibitor valproic acid demonstrated enhanced anticancer activity compared with each agent alone in PC-3, LN-CaP, and Du-145 cells (Wedel et al. $2011 b$ ). In the clinical setting, early results from a phase I/II clinical trial of cixutumumab, an anti-IGF-1R monoclonal antibody, in combination with temsirolimus in patients with chemotherapy-naïve metastatic CRPC have been encouraging; the combination was well tolerated, and for the seven evaluable patients, median time to progression was 32 weeks, with a range of 11-60 weeks (Rathkopf et al. 2011).

\section{Future clinical perspectives}

It is clear from autopsy studies of men with lethal prostate cancer that pathway-activating genomic aberrations in the PI3K pathway occur with a near $100 \%$ prevalence. This is accompanied by frequent aberrations in AR signaling and RAS pathway signaling, illustrating that mutational activation of PI3K does not exist in isolation and requires partners to create a lethal genotype/phenotype. Preclinical studies and early clinical data support the clinical investigation of PI3K/Akt/mTOR pathway inhibitors in combination with other active systemic agents in patients with prostate cancer. Recently, the novel androgendepriving agents abiraterone acetate and enzalutamide have been shown to improve survival of patients with prostate cancer, even after the emergence of castration resistance (de Bono et al. 2011, Scher et al. 2012). Combining these therapies with PI3K/Akt/mTOR inhibitors may further enhance their clinical activity and/or reverse de novo and acquired resistance. Given the likely rapid emergence of resistance to singleagent therapies, initiating therapy with combination approaches would be the preferred route of clinical investigation. Conversely, in order to minimize cost or toxicity with long-term combination approaches, the sequential addition of PI3K inhibition to AR pathway inhibitors upon progression is also worthy of study. A careful analysis of resistance and progression mechanisms in the clinical setting is required through a systematic analysis of circulating and tumor tissue biomarkers relevant to key oncogenic pathways such as

Published by Bioscientifica Ltd 
AR splice variants, RAS pathway activation, and other key oncogenic drivers such as EMT and stemness pathways.

Another important clinical question is the predictive nature of PI3K/Akt/mTOR pathway activation and response to treatment. While there is a wealth of preclinical data implicating the activation of the PI3K/Akt/mTOR pathway in resistance development and enhanced sensitivity to PI3K/Akt/mTOR pathway inhibitors, the clinical validation of the predictive nature of PI3K/Akt/mTOR pathway alterations has been complicated. Obtaining tumor samples for molecular diagnostics is often impractical, and the range of aberrancies in this pathway, including kinase activation and phosphatase inactivation, is complex. Ideally, tumor sampling would occur each time a new treatment is considered, as archival tumor tissue from localized disease may not capture the acquisition of oncogenic events that lead to recurrence and tumor heterogeneity (Gerlinger et al. 2012). To this end, circulating tumor cells (CTCs) and CTC biomarkers may provide an opportunity for the relatively noninvasive molecular assessment of a patient's tumor. AR amplification (Shaffer et al. 2007, Attard et al. 2009, Leversha et al. 2009) and PTEN loss (Attard et al. 2009) have been identified in the CTCs of patients with metastatic CRPC, highlighting the potential for the use of CTCs in biomarker-driven therapy decisions. It should be noted, however, that the only Food and Drug Administrationcleared CTC detection method, CellSearch (Veridex), fails to identify CTCs in as many as $50 \%$ of chemotherapynaïve men with progressive metastatic disease (Dash et al. 2002, de Bono et al. 2008, Scher et al. 2011). Furthermore, due to the use of an epithelial biomarker to capture cells, the CellSearch system is unable to identify cells that have undergone EMT or developed stem cell-like properties (Armstrong et al. 2011). Therefore, improvements in the detection of CTCs may first be necessary before such diagnostic tools can reliably be used for molecular diagnosis of PI3K/Akt/mTOR pathway activation. Technologies that allow for the high-throughput sequencing of CTCs or circulating tumor DNA, RNA, or microRNA are emerging that may permit this personalized biomarkerdriven precision algorithm to proceed more rationally (Diaz et al. 2012).

\section{Conclusions}

The high prevalence of PI3K/Akt/mTOR pathway alterations in prostate cancer, combined with evidence for the involvement of this pathway in the development of castration-resistant disease, has led to the intensive investigation of $\mathrm{PI} 3 \mathrm{~K} / \mathrm{Akt} / \mathrm{mTOR}$ pathway inhibitors in CRPC. While several inhibitors have demonstrated antitumor activity in preclinical models, cross talk and feedback inhibition along parallel pathways may mean that the success of these inhibitors will be dependent on their combination with other targeted or conventional therapies. Clinical trials investigating PI3K/Akt/mTOR pathway inhibitors as single agents and in combination are ongoing in CRPC, and investments are needed to determine predictive biomarkers and the early and late pharmacodynamic effects of these therapies in the clinic.

Declaration of interest

R L Bitting, no conflicts of interest to declare. A J Armstrong, Research support from Novartis, Pfizer/Wyeth, Medivation, Janssen Biotech.

\section{Funding}

Financial support for medical editorial assistance was provided by Novartis Pharmaceuticals.

Author contribution statement

$\mathrm{R} L$ Bitting and A J Armstrong developed the content of the manuscript and drafted the manuscript directly.

\section{Acknowledgements}

The authors thank Amanda Quinn for her medical editorial assistance with this manuscript.

\section{References}

Ackermann TF, Hortnagl H, Wolfer DP, Colacicco G, Sohr R, Lang F, Hellweg R \& Lang UE 2008 Phosphatidylinositide dependent kinase deficiency increases anxiety and decreases GABA and serotonin abundance in the amygdala. Cellular Physiology and Biochemistry 22 735-744. (doi:10.1159/000185557)

Amato RJ, Jac J, Mohammad T \& Saxena S 2008 Pilot study of rapamycin in patients with hormone-refractory prostate cancer. Clinical Genitourinary Cancer 6 97-102. (doi:10.3816/CGC.2008.n.015)

Armstrong AJ, Netto GJ, Rudek MA, Halabi S, Wood DP, Creel PA, Mundy K, Davis SL, Wang T, Albadine R et al. 2010 A pharmacodynamic study of rapamycin in men with intermediate- to high-risk localized prostate cancer. Clinical Cancer Research 16 3057-3066. (doi:10.1158/10780432.CCR-10-0124)

Armstrong AJ, Marengo MS, Oltean S, Kemeny G, Bitting RL, Turnbull JD, Herold CI, Marcom PK, George DJ \& Garcia-Blanco MA 2011 Circulating tumor cells from patients with advanced prostate and breast cancer display both epithelial and mesenchymal markers. Molecular Cancer Research 9 997-1007. (doi:10.1158/1541-7786. MCR-10-0490)

Attard G, Swennenhuis JF, Olmos D, Reid AH, Vickers E, A'Hern R, Levink R, Coumans F, Moreira J, Riisnaes R et al. 2009 Characterization of ERG, AR and PTEN gene status in circulating tumor cells from patients with castration-resistant prostate cancer. Cancer Research 69 2912-2918. (doi:10.1158/0008-5472.CAN-08-3667) http://erc.endocrinology-journals.org DOI: 10.1530/ERC-12-0394
(C) 2013 Society for Endocrinology Printed in Great Britain
Published by Bioscientifica Ltd 
Ayala G, Thompson T, Yang G, Frolov A, Li R, Scardino P, Ohori M, Wheeler T \& Harper W 2004 High levels of phosphorylated form of Akt-1 in prostate cancer and non-neoplastic prostate tissues are strong predictors of biochemical recurrence. Clinical Cancer Research 10 6572-6578. (doi:10.1158/1078-0432.CCR-04-0477)

Baselga J, Campone M, Piccart M, Burris HA, Rugo HS, Sahmoud T, Noguchi S, Gnant M, Pritchard KI, Lebrun F et al. 2012 Everolimus in postmenopausal hormone-receptor-positive advanced breast cancer. New England Journal of Medicine 366 520-529. (doi:10.1056/ NEJMoa1109653)

Bedolla R, Prihoda TJ, Kreisberg JI, Malik SN, Krishnegowda NK, Troyer DA \& Ghosh PM 2007 Determining risk of biochemical recurrence in prostate cancer by immunohistochemical detection of PTEN expression and Akt activation. Clinical Cancer Research 13 3860-3867. (doi:10.1158/1078-0432.CCR-07-0091)

Bendell JC, Rodon J, Burris HA, de Jonge M, Verweij J, Birle D, Demanse D, De Buck SS, Ru QC, Peters M et al. 2012 Phase I, dose-escalation study of BKM120, an oral pan-class I PI3K inhibitor, in patients with advanced solid tumors. Journal of Clinical Oncology 30 282-290. (doi:10.1200/JCO. 2011.36.1360)

Berthold DR, Pond GR, Soban F, de Wit R, Eisenberger M \& Tannock IF 2008 Docetaxel plus prednisone or mitoxantrone plus prednisone for advanced prostate cancer: updated survival in the TAX 327 study. Journal of Clinical Oncology 26 242-245. (doi:10.1200/JCO. 2007.12.4008)

Burris H, Rodon J, Sharma S, Herbst RS, Tabernero J, Infante J, Silva A, Demanse D, Hackl W \& Baselga J 2010 First-in-man phase I study of the oral dual PI3K and mTORC1/2 inhibitor BEZ235 in patients with advanced solid tumors. Journal of Clinical Oncology $\mathbf{2 8}$ abstract 3005.

Busaidy NL, Farooki A, Dowlati A, Perentesis JP, Dancey JE, Doyle LA, Brell JM \& Siu LL 2012 Management of metabolic effects associated with anticancer agents targeting the PI3K-Akt-mTOR pathway. Journal of Clinical Oncology 30 2919-2928. (doi:10.1200/JCO.2011.39.7356)

Carracedo A, Ma L, Teruya-Feldstein J, Rojo F, Salmena L, Alimonti A, Egia A, Sasaki AT, Thomas G, Kozma SC et al. 2008 Inhibition of mTORC1 leads to MAPK pathway activation through a PI3K-dependent feedback loop in human cancer. Journal of Clinical Investigation $\mathbf{1 1 8}$ 3065-3074.

Carver BS, Chapinski C, Wongvipat J, Hieronymus H, Chen Y, Chandarlapaty S, Arora VK, Le C, Koutcher J, Scher H et al. 2011 Reciprocal feedback regulation of PI3K and androgen receptor signaling in PTEN-deficient prostate cancer. Cancer Cell 19 575-586. (doi:10.1016/j.ccr.2011.04.008)

Chee KG, Longmate J, Quinn DI, Chatta G, Pinski J, Twardowski P, Pan CX, Cambio A, Evans CP, Gandara DR et al. 2007 The AKT inhibitor perifosine in biochemically recurrent prostate cancer: a phase II California/Pittsburgh cancer consortium trial. Clinical Genitourinary Cancer 5 433-437. (doi:10.3816/CGC.2007.n.031)

Chen CD, Welsbie DS, Tran C, Baek SH, Chen R, Vessella R, Rosenfeld MG $\&$ Sawyers CL 2004 Molecular determinants of resistance to antiandrogen therapy. Nature Medicine 10 33-39. (doi:10.1038/nm972)

Chen Y, Sawyers CL \& Scher HI 2008 Targeting the androgen receptor pathway in prostate cancer. Current Opinion in Pharmacology 8 440-448. (doi:10.1016/j.coph.2008.07.005)

Courtney KD, Corcoran RB \& Engelman JA 2010 The PI3K pathway as drug target in human cancer. Journal of Clinical Oncology 28 1075-1083. (doi:10.1200/JCO.2009.25.3641)

Dash A, Maine IP, Varambally S, Shen R, Chinnaiyan AM \& Rubin MA 2002 Changes in differential gene expression because of warm ischemia time of radical prostatectomy specimens. American Journal of Pathology $\mathbf{1 6 1}$ 1743-1748. (doi:10.1016/S0002-9440(10)64451-3)

De Bono JS, Scher HI, Montgomery RB, Parker C, Miller MC, Tissing H, Doyle GV, Terstappen LW, Pienta KJ \& Raghavan D 2008 Circulating tumor cells predict survival benefit from treatment in metastatic castration-resistant prostate cancer. Clinical Cancer Research $\mathbf{1 4}$ 6302-6309. (doi:10.1158/1078-0432.CCR-08-0872)
De Bono JS, Oudard S, Ozguroglu M, Hansen S, Machiels JP, Kocak I, Gravis G, Bodrogi I, Mackenzie MJ, Shen L et al. 2010 Prednisone plus cabazitaxel or mitoxantrone for metastatic castration-resistant prostate cancer progressing after docetaxel treatment: a randomised open-label trial. Lancet 376 1147-1154. (doi:10.1016/S0140-6736(10)61389-X)

De Bono JS, Logothetis CJ, Molina A, Fizazi K, North S, Chu L, Chi KN, Jones RJ, Goodman OB, Saad F et al. 2011 Abiraterone and increased survival in metastatic prostate cancer. New England Journal of Medicine 364 1995-2005. (doi:10.1056/NEJMoa1014618)

Diaz LA, Williams RT, Wu J, Kinde I, Hecht JR, Berlin J, Allen B, Bozic I, Reiter JG, Nowak MA et al. 2012 The molecular evolution of acquired resistance to targeted EGFR blockade in colorectal cancers. Nature $\mathbf{4 8 6}$ 537-540.

Dibble CC, Asara JM \& Manning BD 2009 Characterization of Rictor phosphorylation sites reveals direct regulation of mTOR complex 2 by S6K1. Molecular and Cellular Biology 29 5657-5670. (doi:10.1128/MCB. 00735-09)

Ding Z, Wu CJ, Chu GC, Xiao Y, Ho D, Zhang J, Perry SR, Labrot ES, Wu X, Lis $\mathrm{R}$ et al. 2011 SMAD4-dependent barrier constrains prostate cancer growth and metastatic progression. Nature 470 269-273. (doi:10.1038/ nature09677)

Dubrovska A, Kim S, Salamone RJ, Walker JR, Maira SM, Garcia-Echeverria C, Schultz PG \& Reddy VA 2009 The role of PTEN/Akt/PI3K signaling in the maintenance and viability of prostate cancer stem-like cell populations. PNAS 106 268-273. (doi:10.1073/pnas.0810956106)

Dubrovska A, Elliott J, Salamone RJ, Kim S, Aimone LJ, Walker JR, Watson J, Sauveur-Michel M, Garcia-Echeverria C, Cho CY et al. 2010 Combination therapy targeting both tumor-initiating and differentiated cell populations in prostate carcinoma. Clinical Cancer Research $\mathbf{1 6}$ 5692-5702. (doi:10.1158/1078-0432.CCR-10-1601)

Edelman G, Bedell C, Shapiro G, Pandya S, Kwak E, Scheffold C, Nguyen L, Laird A, Baselga J \& Rodon J 2010 A phase I dose-escalation study of XL147 (SAR245408), a PI3K inhibitor administered orally to patients (pts) with advanced malignancies. Journal of Clinical Oncology $\mathbf{2 8}$ abstract 3004.

Edgar KA, Wallin JJ, Berry M, Lee LB, Prior WW, Sampath D, Friedman LS \& Belvin M 2010 Isoform-specific phosphoinositide 3-kinase inhibitors exert distinct effects in solid tumors. Cancer Research 70 1164-1172. (doi:10.1158/0008-5472.CAN-09-2525)

Fang Z, Zhang T, Dizeyi N, Chen S, Wang H, Swanson KD, Cai C, Balk SP \& Yuan X 2012 Androgen receptor enhances p27 degradation in prostate cancer cells through rapid and selective TORC2 activation. Journal of Biological Chemistry 287 2090-2098. (doi:10.1074/jbc.M111.323303)

Festuccia C, Gravina GL, Muzi P, Millimaggi D, Dolo V, Vicentini C \& Bologna M 2008 Akt down-modulation induces apoptosis of human prostate cancer cells and synergizes with EGFR tyrosine kinase inhibitors. Prostate 68 965-974. (doi:10.1002/pros.20757)

Floryk D \& Thompson TC 2008 Perifosine induces differentiation and cell death in prostate cancer cells. Cancer Letters 266 216-226. (doi:10.1016/ j.canlet.2008.02.060)

Fritsch CM, Schnell C, Chatenay-Rivauday C, Guthy DA, De Pover A, Wartmann M, Brachmann S, Maira S, Huang A, Quadt C, et al. 2012 NVP-BYL719, a novel PI3Kalpha selective inhibitor with all the characteristics required for clinical development as an anti-cancer agent. In Proceedings of the 103rd Annual Meeting of the American Association for Cancer Research; 2012 Mar 31-Apr 4; Chicago, Illinois. Philadelphia (PA): AACR abstract 3748.

Fung AS, Wu L \& Tannock IF 2009 Concurrent and sequential administration of chemotherapy and the mammalian target of rapamycin inhibitor temsirolimus in human cancer cells and xenografts. Clinical Cancer Research 15 5389-5395. (doi:10.1158/ 1078-0432.CCR-08-3007)

Furic L, Rong L, Larsson O, Koumakpayi IH, Yoshida K, Brueschke A, Petroulakis E, Robichaud N, Pollak M, Gaboury LA et al. 2010 eIF4E phosphorylation promotes tumorigenesis and is associated with 
prostate cancer progression. PNAS 107 14134-14139. (doi:10.1073/ pnas.1005320107)

George DJ, Armstrong AJ, Creel P, Morris K, Madden J, Turnbull J, Dewhirst M, Major N \& Febbo PG 2008 A phase II study of RAD001 in men with hormone-refractory metastatic prostate cancer (HRPC). Genitourinary Cancers Symposium abstract 181.

Gerlinger M, Rowan AJ, Horswell S, Larkin J, Endesfelder D, Gronroos E, Martinez P, Matthews N, Stewart A, Tarpey P et al. 2012 Intratumor heterogeneity and branched evolution revealed by multiregion sequencing. New England Journal of Medicine 366 883-892.

Gioeli D, Wunderlich W, Sebolt-Leopold J, Bekiranov S, Wulfkuhle JD, Petricoin EF, Conaway M \& Weber MJ 2011 Compensatory pathways induced by MEK inhibition are effective drug targets for combination therapy against castration-resistant prostate cancer. Molecular Cancer Therapeutics 10 1581-1590. (doi:10.1158/1535-7163.MCT-10-1033)

Glickman MS \& Sawyers CL 2012 Converting cancer therapies into cures: lessons from infectious diseases. Cell 148 1089-1098. (doi:10.1016/ j.cell.2012.02.015)

Gross M, Higano C, Pantuck A, Castellanos O, Green E, Nguyen K \& Agus DB 2007 A phase II trial of docetaxel and erlotinib as first-line therapy for elderly patients with androgen-independent prostate cancer. BMC Cancer 7 142. (doi:10.1186/1471-2407-7-142)

Grunwald V, DeGraffenried L, Russel D, Friedrichs WE, Ray RB \& Hidalgo M 2002 Inhibitors of mTOR reverse doxorubicin resistance conferred by PTEN status in prostate cancer cells. Cancer Research 62 6141-6145.

Guba M, von Breitenbuch P, Steinbauer M, Koehl G, Flegel S, Hornung M, Bruns CJ, Zuelke C, Farkas S, Anthuber M et al. 2002 Rapamycin inhibits primary and metastatic tumor growth by antiangiogenesis: involvement of vascular endothelial growth factor. Nature Medicine 8 128-135. (doi:10.1038/nm0202-128)

Guertin DA, Stevens DM, Saitoh M, Kinkel S, Crosby K, Sheen JH, Mullholland DJ, Magnuson MA, Wu H \& Sabatini DM 2009 mTOR complex 2 is required for the development of prostate cancer induced by Pten loss in mice. Cancer Cell 15 148-159. (doi:10.1016/j.ccr.2008. 12.017)

Hsieh AC, Liu Y, Edlind MP, Ingolia NT, Janes MR, Sher A, Shi EY, Stumpf CR, Christensen C, Bonham MJ et al. 2012 The translational landscape of mTOR signalling steers cancer initiation and metastasis. Nature 485 55-61. (doi:10.1038/nature10912)

Ihle NT, Lemos R, Wipf P, Yacoub A, Mitchell C, Siwak D, Mills GB, Dent P, Kirkpatrick DL \& Powis G 2009 Mutations in the phosphatidylinositol3-kinase pathway predict for antitumor activity of the inhibitor PX-866 whereas oncogenic Ras is a dominant predictor for resistance. Cancer Research 69 143-150. (doi:10.1158/0008-5472.CAN-07-6656)

Janku F, Wheler JJ, Naing A, Falchook GS, Hong DS, Stepanek V, Fu S, Piha-Paul SA, Lee JJ \& Luthra R 2012 PIK3CA mutation H1047R is associated with response to PI3K/AKT/mTOR signaling pathway inhibitors in early phase clinical trials. Cancer Research 73 276-284. (doi:10.1158/0008-5472.CAN-12-1726)

Jemal A, Bray F, Center MM, Ferlay J, Ward E \& Forman D 2011 Global cancer statistics. CA: A Cancer Journal for Clinicians 61 69-90. (doi:10.3322/caac.20107)

Jessen K, Kessler L, Kucharski J, Guo X, Staunton J, Janes M, Elia M, Banerjee U, Lan L, Wang S et al. 2011 A potent and selective PI3K inhibitor, INK1117, targets human cancers harboring oncogenic PIK3CA mutations. Molecular Cancer Therapeutics 10 Abstract A171. (doi:10.1158/1535-7163.TARG-11-A171)

Jia S, Liu Z, Zhang S, Liu P, Zhang L, Lee SH, Zhang J, Signoretti S, Loda M, Roberts TM et al. 2008 Essential roles of PI(3)K-p110beta in cell growth, metabolism and tumorigenesis. Nature 454 776-779.

Jia S, Roberts TM \& Zhao JJ 2009 Should individual PI3 kinase isoforms be targeted in cancer? Current Opinion in Cell Biology 21 199-208. (doi:10.1016/j.ceb.2008.12.007)

Jia S, Gao X, Lee SH, Maira SM, Wu X, Stack EC, Signoretti S, Loda M, Zhao JJ \& Roberts TM 2013 Opposing effects of androgen deprivation and targeted therapy on prostate cancer prevention. Cancer Discovery 3 44-51. (doi:10.1158/2159-8290.CD-12-0262)

Jimeno A, Herbst RS, Falchook GS, Messersmith WA, Hecker S, Peterson S, Hausman DF, Kurzrock R, Eckhardt SG \& Hong DS 2010 Final results from a phase I, dose-escalation study of PX-866, an irreversible, pan-isoform inhibitor of PI3 kinase. Journal of Clinical Oncology 28 abstract 3089.

Kantoff PW, Higano CS, Shore ND, Berger ER, Small EJ, Penson DF, Redfern CH, Ferrari AC, Dreicer R, Sims RB et al. 2010 Sipuleucel-T immunotherapy for castration-resistant prostate cancer. New England Journal of Medicine 363 411-422. (doi:10.1056/NEJMoa1001294)

Kinkade CW, Castillo-Martin M, Puzio-Kuter A, Yan J, Foster TH, Gao H, Sun Y, Ouyang X, Gerald WL, Cordon-Cardo C et al. 2008 Targeting AKT/mTOR and ERK MAPK signaling inhibits hormone-refractory prostate cancer in a preclinical mouse model. Journal of Clinical Investigation 118 3051-3064.

Kreisberg JI, Malik SN, Prihoda TJ, Bedolla RG, Troyer DA, Kreisberg S \& Ghosh PM 2004 Phosphorylation of Akt (Ser473) is an excellent predictor of poor clinical outcome in prostate cancer. Cancer Research 64 5232-5236. (doi:10.1158/0008-5472.CAN-04-0272)

Kwitkowski VE, Prowell TM, Ibrahim A, Farrell AT, Justice R, Mitchell SS, Sridhara R \& Pazdur R 2010 FDA approval summary: temsirolimus as treatment for advanced renal cell carcinoma. Oncologist 15 428-435. (doi:10.1634/theoncologist.2009-0178)

Lei Q, Jiao J, Xin L, Chang CJ, Wang S, Gao J, Gleave ME, Witte ON, Liu X \& Wu H 2006 NKX3.1 stabilizes p53, inhibits AKT activation, and blocks prostate cancer initiation caused by PTEN loss. Cancer Cell 9 367-378. (doi:10.1016/j.ccr.2006.03.031)

Leversha MA, Han J, Asgari Z, Danila DC, Lin O, Gonzalez-Espinoza R, Anand A, Lilja H, Heller G, leisher M et al. 2009 Fluorescence in situ hybridization analysis of circulating tumor cells in metastatic prostate cancer. Clinical Cancer Research 15 2091-2097. (doi:10.1158/10780432.CCR-08-2036)

Li Y, Wang Z, Kong D, Li R, Sarkar SH \& Sarkar FH 2008 Regulation of Akt/FOXO3a/GSK-3beta/AR signaling network by isoflavone in prostate cancer cells. Journal of Biological Chemistry 283 27707-27716. (doi:10.1074/jbc.M802759200)

Lim M, Chuong CM \& Roy-Burman P 2011 PI3K, Erk signaling in BMP7-induced epithelial-mesenchymal transition (EMT) of PC-3 prostate cancer cells in 2- and 3-dimensional cultures. Hormones \& Cancer 2 298-309. (doi:10.1007/s12672-011-0084-4)

Lin K 2011 GDC-0068: a novel, selective, ATP-competitive inhibitor of Akt. In Proceedings of the 102nd Annual Meeting of the American Association for Cancer Research; 2011 Apr 2-6; Orlando, Florida. Philadelphia (PA): AACR abstract DDT02-01.

Lin HK, Yeh S, Kang HY \& Chang C 2001 Akt suppresses androgen-induced apoptosis by phosphorylating and inhibiting androgen receptor. PNAS 98 7200-7205. (doi:10.1073/pnas.121173298)

Liu P, Cheng H, Roberts TM \& Zhao JJ 2009 Targeting the phosphoinositide 3-kinase pathway in cancer. Nature Reviews. Drug Discovery 8 627-644. (doi:10.1038/nrd2926)

Lotan TL, Gurel B, Sutcliffe S, Esopi D, Liu W, Xu J, Hicks JL, Park BH, Humphreys E, Partin AW et al. 2011 PTEN protein loss by immunostaining: analytic validation and prognostic indicator for a high risk surgical cohort of prostate cancer patients. Clinical Cancer Research $\mathbf{1 7}$ 6563-6573. (doi:10.1158/1078-0432.CCR-11-1244)

Maira SM, Stauffer F, Brueggen J, Furet P, Schnell C, Fritsch C, Brachmann S, Chene P, De Pover A, Schoemaker K et al. 2008 Identification and characterization of NVP-BEZ235, a new orally available dual phosphatidylinositol 3-kinase/mammalian target of rapamycin inhibitor with potent in vivo antitumor activity. Molecular Cancer Therapeutics 7 1851-1863. (doi:10.1158/1535-7163.MCT-08-0017)

Maira M, Schnell C, Lollini P, Chouaid C, Schmid P, Nanni P, Lam D, Di Tomaso E, Massacesi C \& Rodon J 2012a Preclinical and preliminary clinical activity of NVP-BKM120, an oral pan-class I PI3K inhibitor, in the brain. Annals of Oncology 23 abstract 1675P. 
Maira SM, Pecchi S, Huang A, Burger M, Knapp M, Sterker D, Schnell C, Guthy D, Nagel T, Wiesmann M et al. 2012b Identification and characterization of NVP-BKM120, an orally available pan-class I PI3-Kinase inhibitor. Molecular Cancer Therapeutics 11 317-328. (doi:10.1158/1535-7163.MCT-11-0474)

Majumder PK, Febbo PG, Bikoff R, Berger R, Xue Q, McMahon LM, Manola J, Brugarolas J, McDonnell TJ, Golub TR et al. 2004 mTOR inhibition reverses Akt-dependent prostate intraepithelial neoplasia through regulation of apoptotic and HIF-1-dependent pathways. Nature Medicine 10 594-601. (doi:10.1038/nm1052)

Mazzoletti M, Bortolin F, Brunelli L, Pastorelli R, Di Giandomenico S, Erba E, Ubezio P \& Broggini M 2011 Combination of PI3K/mTOR inhibitors: antitumor activity and molecular correlates. Cancer Research $\mathbf{7 1}$ 4573-4584. (doi:10.1158/0008-5472.CAN-10-4322)

McCubrey JA, Steelman LS, Kempf CR, Chappell WH, Abrams SL, Stivala F, Malaponte G, Nicoletti F, Libra M, Basecke J et al. 2011 Therapeutic resistance resulting from mutations in Raf/MEK/ERK and PI3K/PTEN/Akt/mTOR signaling pathways. Journal of Cellular Physiology 226 2762-2781. (doi:10.1002/jcp.22647)

Mellinghoff IK, Vivanco I, Kwon A, Tran C, Wongvipat J \& Sawyers CL 2004 HER2/neu kinase-dependent modulation of androgen receptor function through effects on DNA binding and stability. Cancer Cell 6 517-527. (doi:10.1016/j.ccr.2004.09.031)

Mellinghoff IK, Cloughesy TF \& Mischel PS 2007 PTEN-mediated resistance to epidermal growth factor receptor kinase inhibitors. Clinical Cancer Research 13 378-381. (doi:10.1158/1078-0432.CCR-06-1992)

Montgomery RB, Mostaghel EA, Vessella R, Hess DL, Kalhorn TF, Higano CS, True LD \& Nelson PS 2008 Maintenance of intratumoral androgens in metastatic prostate cancer: a mechanism for castration-resistant tumor growth. Cancer Research 68 4447-4454. (doi:10.1158/0008-5472.CAN08-0249)

Morgan TM, Pitts TE, Gross TS, Poliachik SL, Vessella RL \& Corey E 2008 RAD001 (everolimus) inhibits growth of prostate cancer in the bone and the inhibitory effects are increased by combination with docetaxel and zoledronic acid. Prostate 68 861-871. (doi:10.1002/pros.20752)

Morikawa Y, Koike H, Sekine Y, Matsui H, Shibata Y, Ito K \& Suzuki K 2012 Rapamycin enhances docetaxel-induced cytotoxicity in a androgenindependent prostate cancer xenograft model by survivin downregulation. Biochemical and Biophysical Research Communications 419 584-589. (doi:10.1016/j.bbrc.2012.02.089)

Mostaghel EA, Marck BT, Plymate SR, Vessella RL, Balk S, Matsumoto AM, Nelson PS \& Montgomery RB 2011 Resistance to CYP17A1 inhibition with abiraterone in castration-resistant prostate cancer: induction of steroidogenesis and androgen receptor splice variants. Clinical Cancer Research 17 5913-5925. (doi:10.1158/1078-0432.CCR-11-0728)

Motzer RJ, Escudier B, Oudard S, Hutson TE, Porta C, Bracarda S, Grunwald V, Thompson JA, Figlin RA, Hollaender N et al. 2008 Efficacy of everolimus in advanced renal cell carcinoma: a double-blind, randomised, placebo-controlled phase III trial. Lancet 372 449-456. (doi:10.1016/S0140-6736(08)61039-9)

Mulholland DJ, Tran LM, Li Y, Cai H, Morim A, Wang S, Plaisier S, Garraway IP, Huang J, Graeber TG et al. 2011 Cell autonomous role of PTEN in regulating castration-resistant prostate cancer growth. Cancer Cell 19 792-804. (doi:10.1016/j.ccr.2011.05.006)

Mulholland DJ, Kobayashi N, Ruscetti M, Zhi A, Tran LM, Huang J, Gleave M \& Wu H 2012 Pten loss and RAS/MAPK activation cooperate to promote EMT and metastasis initiated from prostate cancer stem/ progenitor cells. Cancer Research 72 1878-1889. (doi:10.1158/00085472.CAN-11-3132)

Nakabayashi M, Werner L, Courtney KD, Buckle G, Oh WK, Bubley GJ, Hayes JH, Weckstein D, Elfiky A, Sims DM et al. 2012 Phase II trial of RAD001 and bicalutamide for castration-resistant prostate cancer. BJU International 110 1729-1735. (doi:10.1111/j.1464-410X.2012. 11456.x)

Nanni P, Nicoletti G, Palladini A, Croci S, Murgo A, Ianzano ML, Grosso V, Stivani V, Antognoli A, Lamolinara A et al. 2012 Multiorgan metastasis of human HER-2 $(+)$ breast cancer in Rag2 $(-/-) ; \operatorname{Il} 2 \operatorname{rg}(-/-)$ mice and treatment with PI3K inhibitor. PLOS ONE 7 e39626. (doi:10.1371/ journal.pone.0039626)

O'Reilly KE, Rojo F, She QB, Solit D, Mills GB, Smith D, Lane H, Hofmann F, Hicklin DJ, Ludwig DL et al. 2006 mTOR inhibition induces upstream receptor tyrosine kinase signaling and activates Akt. Cancer Research 66 1500-1508. (doi:10.1158/0008-5472.CAN-05-2925)

Pan C, Robles D, D'Abronzo L, Beggs RE, deVere-White R, Lara P \& Ghosh PM 2012 Synergistic effects of everolimus and bicalutamide in castration-resistant prostate cancer: results from a phase I/II clinical trial [abstract]. Proceedings of the 103rd Annual Meeting of the American Association for Cancer Research; 2012 Mar 31-Apr 4; Chicago, Illinois. Philadelphia (PA): AACR abstract 5750.

Parker C, Heinrich D, O'Sullivan JM, Fossa SD, Chodacki A, Demkow T, Logue JP, Seke M, Widmark A, Johannessen DC et al. 2012 Overall survival benefit and safety profile of radium-223 chloride, a first-in-class alpha-pharmaceutical: results from a phase III randomized trial (ALSYMPCA) in patients with castration-resistant prostate cancer (CRPC) with bone metastases. Journal of Clinical Oncology $\mathbf{3 0}$ abstract 8.

Peterson TR, Laplante M, Thoreen CC, Sancak Y, Kang SA, Kuehl WM, Gray NS \& Sabatini DM 2009 DEPTOR is an mTOR inhibitor frequently overexpressed in multiple myeloma cells and required for their survival. Cell 137 873-886. (doi:10.1016/j.cell.2009.03.046)

Petrylak DP, Tangen CM, Hussain MH, Lara PN, Jones JA, Taplin ME, Burch PA, Berry D, Moinpour C, Kohli M et al. 2004 Docetaxel and estramustine compared with mitoxantrone and prednisone for advanced refractory prostate cancer. New England Journal of Medicine 351 1513-1520. (doi:10.1056/NEJMoa041318)

Pezaro C, Rosenthal MA, Gurney H, Davis ID, Underhill C, Boyer MJ, Kotasek D, Solomon B \& Toner GC 2009 An open-label, single-arm phase two trial of gefitinib in patients with advanced or metastatic castration-resistant prostate cancer. American Journal of Clinical Oncology 32 338-341. (doi:10.1097/COC.0b013e31818b946b)

Posadas EM, Gulley J, Arlen PM, Trout A, Parnes HL, Wright J, Lee MJ, Chung EJ, Trepel JB, Sparreboom A et al. 2005 A phase II study of perifosine in androgen independent prostate cancer. Cancer Biology \& Therapy 4 1133-1137. (doi:10.4161/cbt.4.10.2064)

Pourmand G, Ziaee AA, Abedi AR, Mehrsai A, Alavi HA, Ahmadi A \& Saadati HR 2007 Role of PTEN gene in progression of prostate cancer. Urology Journal 4 95-100.

Prawettongsopon C, Asawakarn S \& Suthiphongchai T 2009 Suppression of prometastatic phenotype of highly metastatic androgen-independent rat prostate cancer MLL cell line by PI3K inhibitor LY294002. Oncology Research 17 301-309. (doi:10.3727/096504009787721195)

Qian DZ, Rademacher BL, Pittsenbarger J, Huang CY, Myrthue A, Higano CS, Garzotto M, Nelson PS \& Beer TM 2010 CCL2 is induced by chemotherapy and protects prostate cancer cells from docetaxelinduced cytotoxicity. Prostate 70 433-442. (doi:10.1002/pros.21077)

Rathkopf DE, Danila DC, Morris MJ, Slovin SF, Borwick LS, Momen L, Curley T, Arauz G, Larson SM, Fleisher M et al. 2011 Anti-insulin-like growth factor-1 receptor (IGF-1R) monoclonal antibody cixutumumab (cix) plus mTOR inhibitor temsirolimus (tem) in metastatic castrationresistant prostate cancer (mCRPC): results of a phase I pilot study. Journal of Clinical Oncology 29 abstract e15081.

Raynaud FI, Eccles SA, Patel S, Alix S, Box G, Chuckowree I, Folkes A, Gowan S, De Haven BA, Di Stefano F et al. 2009 Biological properties of potent inhibitors of class I phosphatidylinositide 3-kinases: from PI-103 through PI-540, PI-620 to the oral agent GDC-0941. Molecular Cancer Therapeutics 8 1725-1738. (doi:10.1158/1535-7163.MCT-08-1200)

Reid AH, Attard G, Ambroisine L, Fisher G, Kovacs G, Brewer D, Clark J, Flohr P, Edwards S, Berney DM et al. 2010 Molecular characterisation of ERG, ETV1 and PTEN gene loci identifies patients at low and high risk of death from prostate cancer. British Journal of Cancer 102 678-684. (doi:10.1038/sj.bjc.6605554)

Renner O, Blanco-Aparicio C, Grassow M, Canamero M, Leal JF \& Carnero A 2008 Activation of phosphatidylinositol 3-kinase by 
membrane localization of p110alpha predisposes mammary glands to neoplastic transformation. Cancer Research 68 9643-9653. (doi:10. 1158/0008-5472.CAN-08-1539)

Rhodes N, Heerding DA, Duckett DR, Eberwein DJ, Knick VB, Lansing TJ, McConnell RT, Gilmer TM, Zhang SY, Robell K et al. 2008 Characterization of an Akt kinase inhibitor with potent pharmacodynamic and antitumor activity. Cancer Research 68 2366-2374. (doi:10.1158/00085472.CAN-07-5783)

Rini BI \& Small EJ 2002 Hormone-refractory prostate cancer. Current Treatment Options in Oncology 3 437-446. (doi:10.1007/s11864-0020008-1)

Rodrik-Outmezguine VS, Chandarlapaty S, Pagano NC, Poulikakos PI, Scaltriti M, Moskatel E, Baselga J, Guichard S \& Rosen N 2011 mTOR kinase inhibition causes feedback-dependent biphasic regulation of AKT signaling. Cancer Discovery 1 248-259. (doi:10.1158/2159-8290. CD-11-0085)

Sarbassov DD, Guertin DA, Ali SM \& Sabatini DM 2005 Phosphorylation and regulation of Akt/PKB by the rictor-mTOR complex. Science $\mathbf{3 0 7}$ 1098-1101. (doi:10.1126/science.1106148)

Sarbassov DD, Ali SM, Sengupta S, Sheen JH, Hsu PP, Bagley AF, Markhard AL \& Sabatini DM 2006 Prolonged rapamycin treatment inhibits mTORC2 assembly and Akt/PKB. Molecular Cell 22 159-168. (doi:10.1016/j.molcel.2006.03.029)

Sarker D, Reid AH, Yap TA \& de Bono JS 2009 Targeting the PI3K/AKT pathway for the treatment of prostate cancer. Clinical Cancer Research 15 4799-4805. (doi:10.1158/1078-0432.CCR-08-0125)

Schayowitz A, Sabnis G, Goloubeva O, Njar VC \& Brodie AM 2010 Prolonging hormone sensitivity in prostate cancer xenografts through dual inhibition of AR and mTOR. British Journal of Cancer 103 1001-1007. (doi:10.1038/sj.bjc.6605882)

Scher HI, Morris MJ, Basch E \& Heller G 2011 End points and outcomes in castration-resistant prostate cancer: from clinical trials to clinical practice. Journal of Clinical Oncology 29 3695-3704. (doi:10.1200/JCO. 2011.35.8648)

Scher HI, Fizazi K, Saad F, Taplin ME, Sternberg CN, Miller K, de Wit R, Mulders P, Chi KN, Shore ND et al. 2012 Increased survival with enzalutamide in prostate cancer after chemotherapy. New England Journal of Medicine 367 1187-1197. (doi:10.1056/NEJMoa1207506)

Shaffer DR, Leversha MA, Danila DC, Lin O, Gonzalez-Espinoza R, Gu B, Anand A, Smith K, Maslak P, Doyle GV et al. 2007 Circulating tumor cell analysis in patients with progressive castration-resistant prostate cancer. Clinical Cancer Research 13 2023-2029. (doi:10.1158/10780432.CCR-06-2701)

Shapiro G, LoRusso P, Kwak EL, Cleary JM, Musib L, Jones C, de Crespigny A, Belvin M, McKenzie M, Gates MR et al. 2011 Clinical combination of the MEK inhibitor GDC-0973 and the PI3K inhibitor GDC-0941: a firstin-human phase Ib study testing daily and intermittent dosing schedules in patients with advanced solid tumors [abstract]. Journal of Clinical Oncology 29 abstract 3005.

Siegel R, Naishadham D \& Jemal A 2012 Cancer statistics, 2012. CA: A Cancer Journal for Clinicians 2012 10-29. (doi:10.3322/caac.20138)

Skvortsova I, Skvortsov S, Stasyk T, Raju U, Popper BA, Schiestl B, von Guggenberg E, Neher A, Bonn GK, Huber LA et al. 2008 Intracellular signaling pathways regulating radioresistance of human prostate carcinoma cells. Proteomics 8 4521-4533. (doi:10.1002/pmic. 200800113)

Small EJ, Fontana J, Tannir N, DiPaola RS, Wilding G, Rubin M, Iacona RB \& Kabbinavar FF 2007 A phase II trial of gefitinib in patients with nonmetastatic hormone-refractory prostate cancer. BJU International 100 765-769. (doi:10.1111/j.1464-410X.2007.07121.x)

Sparks CA \& Guertin DA 2010 Targeting mTOR: prospects for mTOR complex 2 inhibitors in cancer therapy. Oncogene 29 3733-3744. (doi:10.1038/onc.2010.139)

Sridhar SS, Hotte SJ, Chin JL, Hudes GR, Gregg R, Trachtenberg J, Wang L, Tran-Thanh D, Pham NA, Tsao MS et al. 2010 A multicenter phase II clinical trial of lapatinib (GW57) in hormonally untreated advanced prostate cancer. American Journal of Clinical Oncology 33 609-613. (doi:10.1097/COC.0b013e3181beac33)

Taylor BS, Schultz N, Hieronymus H, Gopalan A, Xiao Y, Carver BS, Arora VK, Kaushik P, Cerami E, Reva B et al. 2010 Integrative genomic profiling of human prostate cancer. Cancer Cell 18 11-22. (doi:10.1016/ j.ccr.2010.05.026)

Templeton A, Rothermundt C, Cathomas R, Baertschi D, Droege C, Gautschi O, Borner MM, Fechter E, Stenner F, Winterhalder RC et al. 2011 Everolimus as first-line therapy in nonrapidly progressive metastatic castration-resistant prostate cancer (mCRPC): a multicenter phase II trial (SAKK 08/08). Journal of Clinical Oncology 29 abstract 4588 .

Vasudevan KM, Barbie DA, Davies MA, Rabinovsky R, McNear CJ, Kim JJ, Hennessy BT, Tseng H, Pochanard P, Kim SY et al. 2009 AKTindependent signaling downstream of oncogenic PIK3CA mutations in human cancer. Cancer Cell 16 21-32. (doi:10.1016/j.ccr.2009.04.012)

Von Hoff DD, LoRusso P, Tibes R, Shapiro G, Weiss GJ, Ware JA, Fredrickson J, Mazina KE, Levy GG \& Wagner AJ 2010 A first-in-human phase I study to evaluate the pan-PI3K inhibitor GDC-0941 administered QD or BID in patients with advanced solid tumors. Journal of Clinical Oncology 28 abstract 2541. (doi:10.1200/JCO.2009.26.5983)

Wagner AJ, Bendell JC, Dolly S, Morgan JA, Ware JA, Fredrickson J, Mazina KE, Lauchle JO, Burris HA \& De Bono JS 2011 A first-in-human phase I study to evaluate GDC-0980, an oral PI3K/mTOR inhibitor, administered QD in patients with advanced solid tumors. Journal of Clinical Oncology 29 abstract 3020.

Wallin JJ, Edgar KA, Guan J, Berry M, Prior WW, Lee L, Lesnick JD, Lewis C, Nonomiya J, Pang J et al. 2011 GDC-0980 is a novel class I PI3K/mTOR kinase inhibitor with robust activity in cancer models driven by the PI3K pathway. Molecular Cancer Therapeutics 10 2426-2436. (doi:10.1158/1535-7163.MCT-11-0446)

Wang S, Gao J, Lei Q, Rozengurt N, Pritchard C, Jiao J, Thomas GV, Li G, Roy-Burman P, Nelson PS et al. 2003 Prostate-specific deletion of the murine Pten tumor suppressor gene leads to metastatic prostate cancer. Cancer Cell 4 209-221. (doi:10.1016/S1535-6108(03)00215-0)

Watson PA, Chen YF, Balbas MD, Wongvipat J, Socci ND, Viale A, Kim K \& Sawyers CL 2010 Constitutively active androgen receptor splice variants expressed in castration-resistant prostate cancer require full-length androgen receptor. PNAS 107 16759-16765. (doi:10.1073/pnas. 1012443107)

Wedel S, Hudak L, Seibel JM, Juengel E, Tsaur I, Haferkamp A \& Blaheta RA $2011 a$ Combined targeting of the VEGFr/EGFr and the mammalian target of rapamycin (mTOR) signaling pathway delays cell cycle progression and alters adhesion behavior of prostate carcinoma cells. Cancer Letters 301 17-28. (doi:10.1016/j.canlet.2010.11.003)

Wedel S, Hudak L, Seibel JM, Makarevic J, Juengel E, Tsaur I, Waaga-Gasser A, Haferkamp A \& Blaheta RA 2011 $b$ Molecular targeting of prostate cancer cells by a triple drug combination down-regulates integrin driven adhesion processes, delays cell cycle progression and interferes with the cdk-cyclin axis. BMC Cancer 11 375. (doi:10.1186/ 1471-2407-11-375)

Wen Y, Hu MC, Makino K, Spohn B, Bartholomeusz G, Yan DH \& Hung MC 2000 HER-2/neu promotes androgen-independent survival and growth of prostate cancer cells through the Akt pathway. Cancer Research $\mathbf{6 0}$ 6841-6845.

Whang YE, Armstrong AJ, Rathmell WK, Godley PA, Kim WY, Pruthi RS, Wallen EM, Crane JM, Moore DT \& Grigson G 2011 A phase II study of lapatinib, a dual EGFR and HER-2 tyrosine kinase inhibitor, in patients with castration-resistant prostate cancer. Urologic Oncology 31 82-86. (doi:10.1016/j.urolonc.2010.09.018)

Wu L, Birle DC \& Tannock IF 2005 Effects of the mammalian target of rapamycin inhibitor CCI-779 used alone or with chemotherapy on human prostate cancer cells and xenografts. Cancer Research 65 2825-2831. (doi:10.1158/0008-5472.CAN-04-3137)

Yamnik RL, Digilova A, Davis DC, Brodt ZN, Murphy CJ \& Holz MK 2009 S6 kinase 1 regulates estrogen receptor alpha in control of breast cancer 
cell proliferation. Journal of Biological Chemistry 284 6361-6369. (doi:10.1074/jbc.M807532200)

Yao JC, Shah MH, Ito T, Bohas CL, Wolin EM, Van Cutsem E, Hobday TJ, Okusaka T, Capdevila J, de Vries EG et al. 2011 Everolimus for advanced pancreatic neuroendocrine tumors. New England Journal of Medicine 364 514-523. (doi:10.1056/NEJMoa1009290)

Zhang W, Zhu J, Efferson CL, Ware C, Tammam J, Angagaw M, Laskey J, Bettano KA, Kasibhatla S, Reilly JF et al. 2009 Inhibition of tumor growth progression by antiandrogens and mTOR inhibitor in a Pten-deficient mouse model of prostate cancer. Cancer Research 69 7466-7472. (doi:10.1158/0008-5472.CAN-08-4385)

Ziada A, Barqawi A, Glode LM, Varella-Garcia M, Crighton F, Majeski S, Rosenblum M, Kane M, Chen L \& Crawford ED 2004 The use of trastuzumab in the treatment of hormone refractory prostate cancer; phase II trial. Prostate 60 332-337. (doi:10.1002/ pros.20065)

Received in final form 22 February 2013

Accepted 1 March 2013

Made available online as an Accepted Preprint

1 March 2013
Published by Bioscientifica Ltd. 